\title{
Exploring intra-commonwealth goods and services trade ${ }^{1}$
}

\author{
Anirudh Shingal $^{2}$ and Mohammad Razzaque ${ }^{3}$
}

March 2015

\begin{abstract}
Existing work examining the trade effect of commonwealth membership does not account for sample selection, unobserved heterogeneity and multilateral resistance in estimation, leading to biased estimates. Our analyses improve on all these fronts. Unlike earlier work, we also consider services trade and assemble a much larger sample of trading partners (242 x 242, over 1995-2010). Commonwealth membership is found to increase goods exports by 18.5$33.2 \%$ and services exports by $42.8 \%$ in our results, ceteris paribus and on average. Our analyses on the determinants of intra-commonwealth trade suggest the positive role of common language (only for goods trade) and colonial relationships as well as the negative impact of geography, thereby confirming that commonwealth member states are not natural trading partners for each other. Finally, being one of Australia, Canada or the UK is associated with $98.2 \%$ greater merchandise trade than the commonwealth average; however, a similar effect is not observed for services trade.
\end{abstract}

JEL codes: F10, F14

Key words: Commonwealth, trade, sample selection, high-dimensional fixed effects, multilateral resistance, bilateral trade costs

\footnotetext{
${ }^{1}$ Prepared as background paper for the Commonwealth Secretariat's 2015 flagship trade publication, 'The Commonwealth in the Unfolding Global Trade Landscape: Prospects | Priorities | Perspectives', available at: http://thecommonwealth.org/commonwealth-unfolding-global-trade-landscape\#sthash.ND9cli1a.dpuf

${ }^{2}$ Corresponding author; World Trade Institute, University of Bern (anirudh.shingal@wti.org).

${ }^{3}$ Commonwealth Secretariat, London (m.razzaque@commonwealth.int)
} 


\section{Introduction}

With one quarter of the world's governments, one third of the world's population and one fifth of global trade, the Commonwealth (CW) is a diverse community of nations sharing an inheritance of a common language, institutions and culture. It brings together a unique range of countries, comprising rich and poor, large and small, as well as island, landlocked and coastal states. The association boasts the 'Commonwealth culture' of amicable partnership, in which activities are conducted in an atmosphere of co-operation and with a shared sense of community, reflecting its members' common traditions and shared values; this culture has inspired a high level of engagement among $\mathrm{CW}$ members. The unique mix of characteristics and strengths permits the $\mathrm{CW}$ to serve as a catalyst for genuine engagement, understanding and progress at the international level.

International co-operation in trade is increasingly prevalent and notwithstanding the somewhat unclear gains from trading blocs and their implications for multilateral free trade, preferential trading agreements (PTAs) have become a prominent feature of the world trading system, which has witnessed as many as 585 trading blocs being notified to the GATT/WTO. Almost all CW nations are members of at least one PTA and many of them have signed up to several such arrangements.

The CW also has a commendable track record of north-south and south-south collaboration, which provides a sound basis for co-operation targeted specifically at expanding and building inter-country and inter-regional trading links. The clear desire and spirit of co-operation among members is reflected in numerous CW-sponsored initiatives in both regional and multilateral forums. These strengths place the organisation in a privileged position to provide support, through the joint action of its members, for furthering the attainment of their goals of expanded trade and improved welfare.

In 2013 Colombo Meeting, the Commonwealth Heads of Governments issued a standalone statement on trade where amongst others they categorically mentioned, “[W]e recognize the potential for growth in intra-Commonwealth trade and investment as well as the importance of promoting practical measures to overcome constraints to such growth.” This is also now quite well-understood that trade between a group of countries can be promoted even in the absence of trade policy-induced support (as it is in the case of the Commonwealth which is not a trading bloc as such). In fact, the 2013 World Trade Report suggests that on average only about $16 \%$ of all trade that takes place within regional trading blocs is preferential in nature. The rise of global value chains and the widespread recognition of improved trade facilitation measure as determinants of increased trade flows merit the case for non-policy induced trade cooperation within the Commonwealth.

Against this background, this study assembles bilateral trade flow data on goods and services for 242 countries over 1995-2010 and uses both descriptive statistics and more sophisticated econometric techniques to understand the nature and structure of intra-CW trade, its determinants, and the trade effect of being a part of the CW. The study also discusses measures available to enhance intra-CW trade. 
While there is existing literature on this subject that is reviewed in the following section, none of the other econometric studies account for the presence of zero trade flows between bilateral trading partners, unobserved heterogeneity and multilateral resistance terms (MRT) in estimation, thus leading to biased estimates. Our analyses are an improvement on all these fronts.

Moreover, the existing econometric studies only look at trade in merchandise goods. To the best of our knowledge, this is the first paper that also studies the "commonwealth" effect on services trade using a recent data set on bilateral services trade, the "trade in services database" (TSD; Francois \& Pindyuk, 2013). The TSD compiles data on cross-border services flows between 251 reporting and 251 partner countries over 1981-2010 using different sources such as the OECD, Eurostat and UNSD.

In our results, commonwealth membership is found to increase goods exports by 18.5-33.2\% and services exports by $42.8 \%$, ceteris paribus and on average. Our analyses on the determinants of intra-CW goods and services trade suggest the positive role of common language (only for goods trade) and colonial relationships as well as the negative impact of geography (both distance and contiguity), thereby confirming that commonwealth member states are not natural trading partners for each other. Our empirical analyses also document the importance of the Asian CW region as both a source of and destination for intra-CW goods and services trade. Finally, being one of Australia, Canada and the UK is associated with $98.2 \%$ greater merchandise trade than the average within the commonwealth member states. However, a similar effect is not observed in the case of services trade.

\section{Literature review}

The first notable attempt to analyse the significance of a 'Commonwealth effect' on trade and investment was made in the late 1990s by Lundan and Jones (2001) taking data on 53 CW and 18 non-CW countries to the gravity model. Their findings suggested an overall tendency for high levels of intra-CW trade and investment, controlling for geography and policy factors such as common PTAs. The authors also noted that simple linear predictions of future trade shares showed a gradual decline in intra-CW trade in the decade ahead.

A report by Chris Milner for the Commonwealth Secretariat (2008) inter alia explored the determinants of intra-CW trade in merchandise goods for the year 2003. Apart from the dummy variable for being landlocked, all other standard gravity variables were statistically significant and the effect of geography, infrastructure and economic size in particular on intra-CW trade was found to be large.

Bennett et. al (2010) estimated the effect of CW membership on exports and imports separately using a larger sample of countries and years (1990-2008). They found a 'Commonwealth effect' of around 50 per cent for imports and around 38 per cent for exports in their fully-specified gravity estimation. In their descriptive statistics, the authors also found that the proportion of $\mathrm{CW}$ trade tends to be higher in countries where the overall volume of trade is lower, a finding which is consistent with ours and Lundan and Jones (2001). 
Finally, more recently, ITC (2013) and Standard Chartered (2014) have explored recent trends in intra-CW trade using descriptive statistics. The ITC (2013) study finds that "commonwealth countries have experienced different performances in terms of exports over the last years. While Least developed countries (LDCs) were least affected by the 2008/2009 economic crisis, they have also benefited from the strongest recovery. However, their performance remains fragile because of their high dependence on few products many of which are exported without any value addition. Furthermore, while developing countries inside and outside the Commonwealth become more and more important as export destinations, intra-Commonwealth trade has not stepped up in the past years."

Standard Chartered (2014) note that while the CW is not a natural trading bloc, it is again beginning to gain relevance. While CW trade is dominated by a few members, intra-CW trade is beginning to pick up and the rapid growth of the many emerging economies within the CW only bodes well for future growth.

However, none of the econometric studies accounted for the presence of zero trade flows between bilateral trading partners, unobserved heterogeneity and multilateral resistance terms (MRT) in estimation, thus leading to biased estimates. Moreover, they only studied trade in merchandise goods. Our analyses are an improvement on all these fronts.

We include importer-time and exporter-time fixed effects, which not only control for unobserved heterogeneity in estimation but also account for MRT (for instance see Anderson \& van Wincoop, 2003, 2004; Baier \& Bergstrand, 2007), thereby making our empirical analyses consistent with recent advancements in the estimation of structural gravity models.

Given the large size of our panel (242 countries, 16 years), the use of two high-dimensional fixed effects (HDFE) in estimation leads to computational problems. To circumvent these issues, we employ the "2WFE" estimator developed by Guimaraes and Portugal (2010) to accommodate HDFE in estimation. We also account for the existence of zero trade flows in our data by following the approach of Eaton and Kortum (2001). This makes ours the first paper to explore the CW trade effect accounting for the possibility that not all countries trade in all products and that too, for both goods and services trade. Finally, we assemble a much larger sample of bilateral trading partners (242 countries each) than in the existing literature.

\section{Exploring the 'commonwealth effect' on trade}

Our empirical analysis is conducted in the framework of the gravity model as laid down by Anderson (1979) which is based on identical consumer preferences modelled by Constant Elasticity of Substitution (CES) utility functions and with Armington assumption of preference for domestically produced goods. Following Anderson (2004), the value of exports from country i to country $\mathrm{j}$ can be written as follows:

$$
X i j=\frac{E j Y i}{Y}\left(\frac{T i j}{P j \pi i}\right)^{(1-\sigma)}
$$


where $X_{i j}$ denotes the value of exports, $E_{j}$ is the expenditure in the destination country $j, Y_{i}$ denotes the total sales of exporter $\mathrm{i}$ towards all destinations, $\mathrm{Y}$ is the total world output, $\mathrm{T}_{\mathrm{ij}}$ are the iceberg trade costs and $\sigma$ is the elasticity of substitution across goods and services. $P_{j}$ and $\Pi_{\mathrm{i}}$, the multilateral Resistance Terms (MRTs), are the inward and outward relative resistance of a country's exports towards all destinations and from all origins. Outward multilateral resistance captures the fact that trade flows between $\mathrm{i}$ and $\mathrm{j}$ depend on trade costs across all potential markets for i's exports; inward multilateral resistance captures the fact that bilateral trade depends on trade costs across all potential import markets too. The two indices thus summarize average trade resistance between a country and its trading partners.

Because the MRT are difficult to construct directly as national price indices are needed (which are not available for all countries at a disaggregated level), applications of the gravity model have resorted to using dummy variables to control for them instead. Following Baier \& Bergstrand (2007) we therefore use importer-time and exporter-time fixed effects to account for the MRTs.

We proxy trade costs by bilateral distance between trading partners, $\ln \left(\right.$ Dist $\left._{i j}\right)$, as well as the usual gravity model controls which include dummy variables identifying whether the trading partners share a common border (Contig ${ }_{\mathrm{ij}}$ ), have/had a colonial relationship (Colony $\mathrm{ij}_{\mathrm{ij}}$ ), share a common language (Lang $\left.{ }_{\mathrm{ij}}\right)$, a common legal system ( Leg $\left._{\mathrm{ij}}\right)$ and a common currency $\left(\mathrm{Cur}_{\mathrm{ij}}\right)$.

Introducing dummy variables for membership of trade agreements $\left(\mathrm{PTA}_{\mathrm{ijt}}\right)$ and membership of the commonwealth $\left(\mathrm{CW}_{\mathrm{ij}}\right)$, which is our variable of interest, substituting the MRTs with the appropriate fixed effects, adding the proxies for trade costs and taking the logarithm of this transformed version of equation (1) yields the following:

$$
\begin{aligned}
\operatorname{lnXijt}=\alpha i t & +\beta j t+\beta 1 C W i j+\beta 2 P T A i j t+\beta 3 \ln (\text { Distij })+\beta 4 \text { Contigij } \\
& +\beta 5 \text { Langij }+\beta 6 \text { Colij }+\beta 7 \text { Legij }+\beta 8 \text { Curij }+ \text { eijt } \ldots \ldots \ldots . . . .
\end{aligned}
$$

where $\alpha_{\mathrm{it}}$ and $\beta_{\mathrm{jt}}$ are the fixed effects that proxy the MRTs.

\section{Estimation issues}

Our equations can be estimated log-linearly using ordinary least squares (OLS). However, this excludes the treatment of export zeroes (as the log of zero is not defined) and the incidence of export zeroes was fairly high in our data, especially for services trade (see next section for details). Selection of the appropriate estimator in the presence of zeroes is contingent on the process generating the error term. Following Head and Mayer (2013), we found our goods and services trade data to be characterized by a constant variance to mean ratio which suggested the use of the Poisson pseudo-maximum likelihood (PPML) for inference. Unfortunately, PPML estimation with several HDFE as in our estimating equations led to non-convergence. This did not change even with the application of different workaround strategies suggested by Santos Silva and Tenreyro (2010).

Given the large size of our panel (242 countries, 16 years), the use of two high-dimensional fixed effects (HDFE) in estimation leads to computational problems. To circumvent these 
issues, we use the "2WFE" approach developed by Guimaraes and Portugal (2010). This allows for estimating linear regressions model with two high-dimensional fixed effects with minimal memory requirements. Head and Mayer (2013) find the 2WFE estimator to provide identical estimates to the least squares dummy variable (Harrigan, 1996) without being subject to arbitrary limits. They also recommend the 2WFE over other estimation strategies such as double-demeaning, Bonus Vetus OLS (Baier and Bergstrand 2009) and tetrads (Head et al 2010).

Thus, we estimated our equations log-linearly using the 2WFE estimator. However, this strategy would only work at the intensive margin. To include export zeroes in the 2WFE estimation, we followed the approach of Eaton and Kortum (2001) and assumed that there was a minimum level of exports for each destination market such that when gravity-predicted exports was less than this minimum level, the observed value of exports was zero. This minimum level of exports is approximated by the minimum observed exports for each destination market $\left(\min X_{j}\right)$.

Unlike the practice of adding an arbitrary constant to the export zeroes, this approach is more intuitive as the minimum trade flow for a specific importer would tend to reflect differences in market size, competition and trade barriers, as well as reporting and measurement issues.

Thus, the goods and services trade equations were estimated log-linearly by replacing $X_{i j t}$ with $\left(X_{i j t}+\min X_{j}\right)$ to incorporate the export zeroes in the analyses. Since $\min X_{j}$ is the level of minimum observed exports for each destination market, data on these were already present in our data set.

\section{Data}

To explore the commonwealth effect on trade, we assemble a database of bilateral trade in goods and services between 242 countries over 1995-2010, including the 53 countries of the CW. Data on bilateral goods trade are taken from UN Comtrade, that on bilateral services trade are taken from Francois \& Pindyuk (2013) and data on standard gravity controls are taken from CEPII. The dummy variable on PTA membership is constructed using information from the WTO's RTA-IS database.

Summary statistics are provided in Annex Table 1 . The full sample has more than 100,000 observations but export value is positive for only $77.5 \%$ of these for goods trade and $57.1 \%$ for services trade. Of the full sample, 32430 observations (30.8\%) include at least one country from the CW, while 2626 observations (2.5\%) are on intra-CW trade. Of these 2626 observations on intra-CW trade, $89 \%$ report positive goods trade and $69.7 \%$ report positive services trade. Thus, both $\mathrm{CW}$ and non-CW countries in our data report a significant number of zero trade flows for both goods and services. 


\subsection{Trade in goods}

Trade amongst CW countries (forecast ${ }^{4}$ at $\$ 575.8$ bn in 2015) is becoming an important part of the CW's total merchandise trade (forecast at $\$ 3.25$ tr in 2015; see Figure 1). Commonwealth merchandise trade with the world as a share of global merchandise trade fell from $16.7 \%$ in 1995 to $13.5 \%$ in 2010 (and projected to fall further to $12.2 \%$ in 2015), even though world merchandise trade grew from \$4.6 trillion (tr) in 1995 to \$16.4 tr in 2010 (and projected to rise further to $\$ 26.6$ tr in 2015). At the same time, intra-commonwealth merchandise trade as a share of commonwealth merchandise trade with the world increased from $14.4 \%$ in 1995 to $16.8 \%$ in 2010 (and is projected to rise further to $17.7 \%$ in 2015), though the share of intra-commonwealth merchandise trade in world merchandise trade remains stagnant at $2.2 \%$. Note that "average” in all these figures denotes the average of imports and exports.

Figure 1: World, commonwealth and intra- $\mathrm{CW}$ average goods trade over time

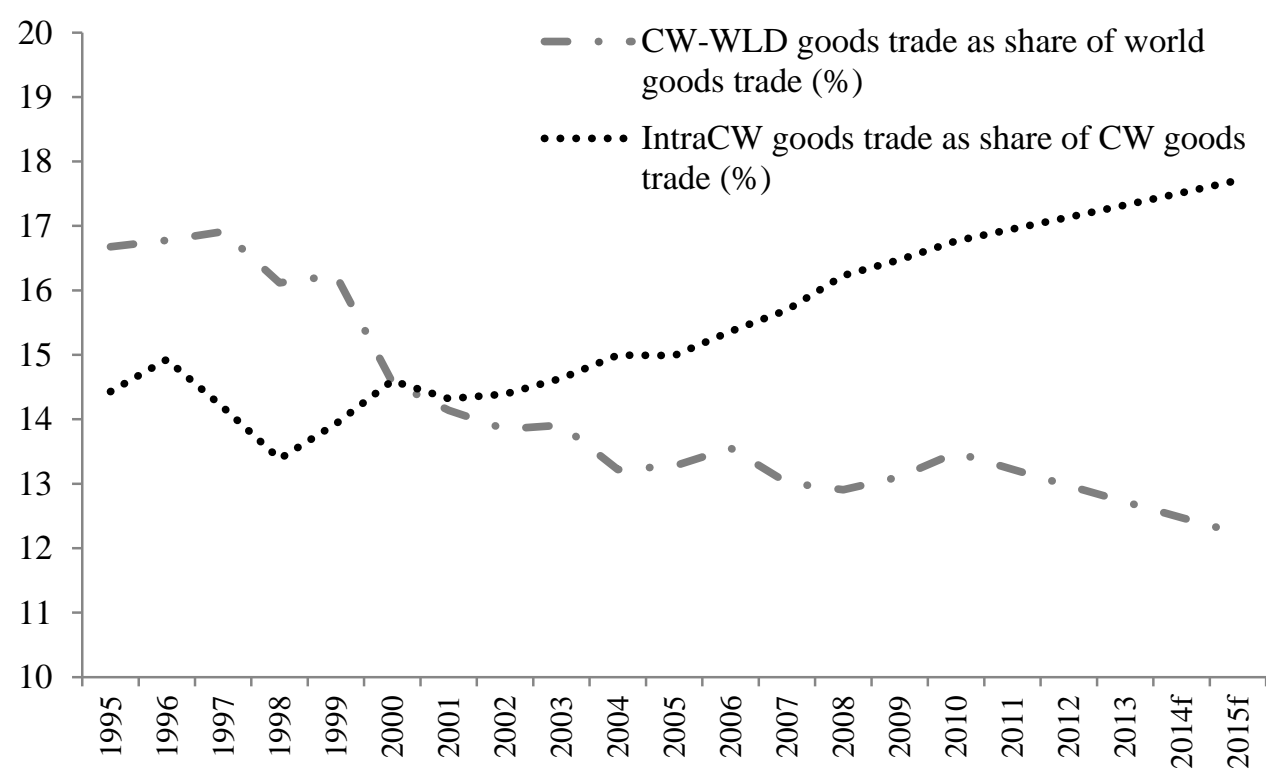

Source: UN Comtrade; own calculations

The top ten CW trading countries globally accounted for $94.7 \%$ of the CW's trade with the world in 2010, revealing a highly skewed distribution (see Figure 2). In fact, just the top two countries, UK and Canada, contributed more than half of the CW's average trade with the world. The geographical distribution of the CW's average goods trade with the world also reveals the much greater importance of India over time; the comparatively lesser importance of the UK and Canada; and the emergence of Nigeria and Pakistan in the list of top ten CW trading nations in 2010.

\footnotetext{
4 The forecasts made in this study for goods trade fit exponential functions to goods trade values over 19952010 to project future goods trade values.
} 
Figure 2: Direction of commonwealth average goods trade (\% shares, $1995 \mathrm{v} 2010$ )
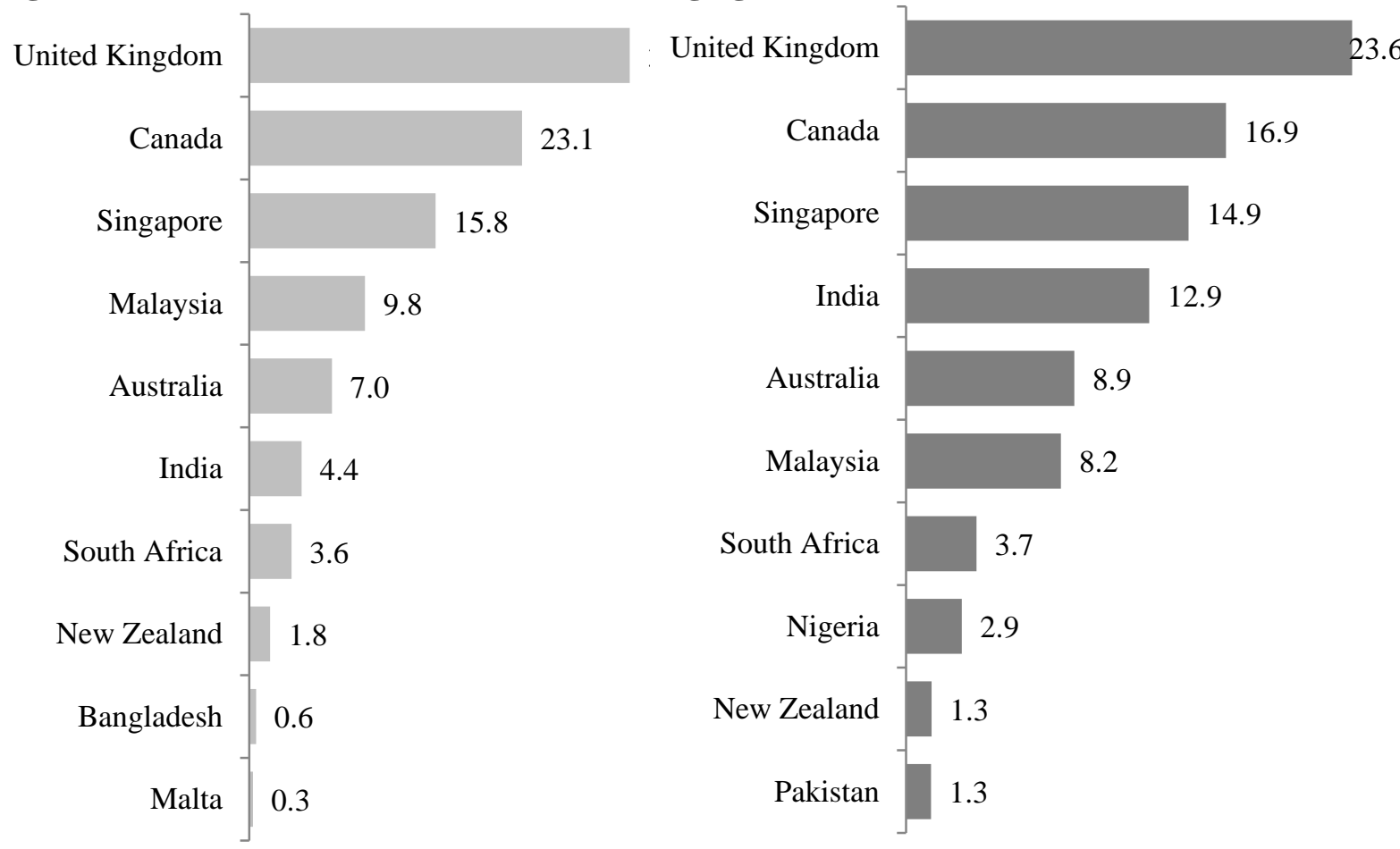

Figure 3: Direction of intra-commonwealth avg. goods trade (\% shares, $1995 \mathrm{v}$ 2010)
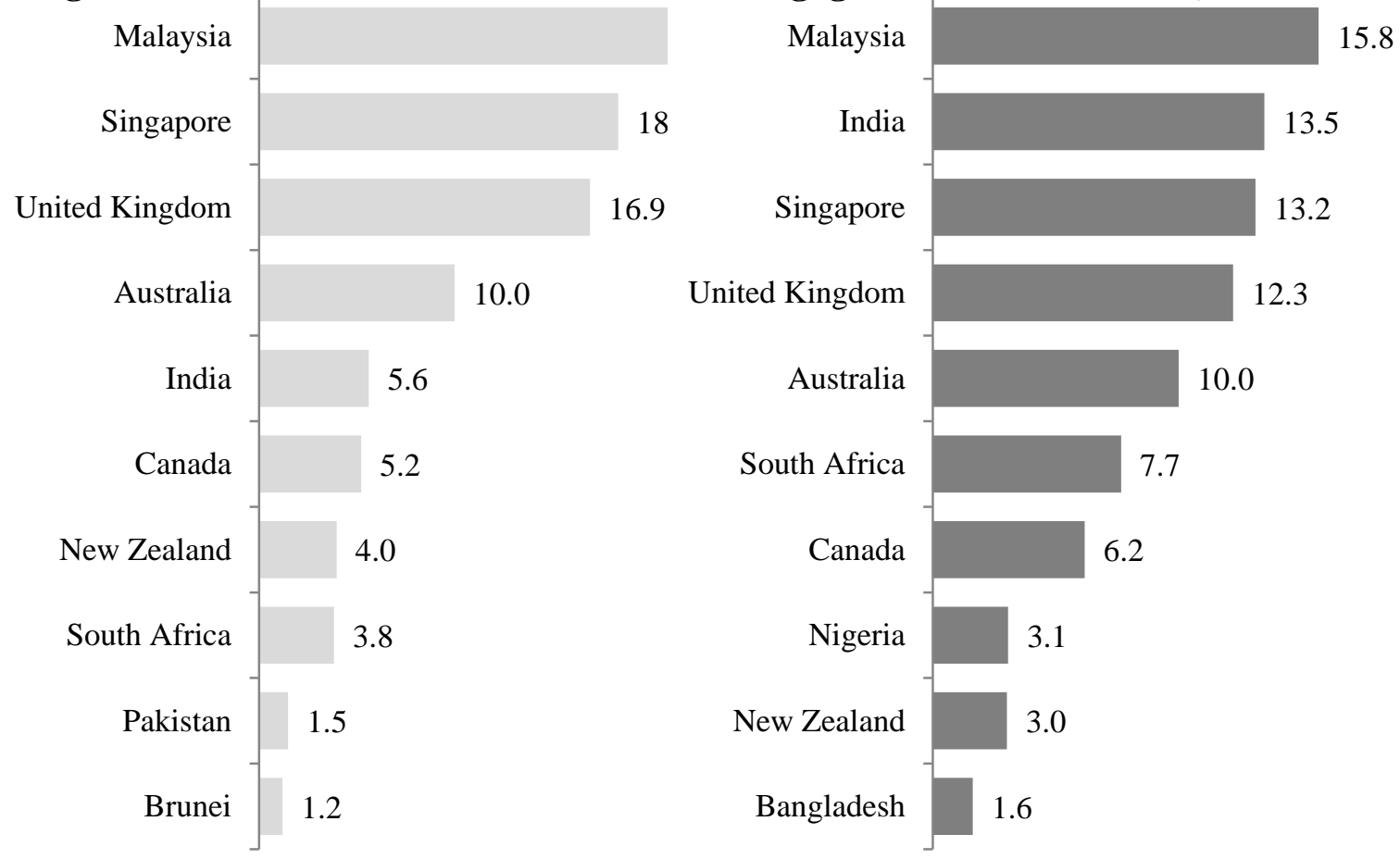

Source: UN Comtrade; own calculations

The ranking of the top ten CW trading countries globally in 2010 is different from the ranking of the top ten intra-CW trading countries in the same year (see Figures 2 and 3). Even over time, while the UK has been the largest CW trader globally, Malaysia has been the largest intra-CW trader. In contrast, the top ten intra-CW trading countries accounted for 
86.4\% of intra-CW trade in 2010, suggesting that the distribution was comparatively less skewed. Thus, the last four CW "trade quintiles" trade more amongst each other than with ROW, suggesting that the low-trade-volume CW countries may find the CW easier to trade with compared to the rest of the world (ROW), a finding which is consistent with Lundan \& Jones (2001) and Bennett et.al (2010).

The direction of intra-CW goods imports (\$ 361.2 bn in 2010) is primarily Asian in origin (see Figure 4). Nearly $50 \%$ of intra-CW goods imports originate from Asia and this region's importance did not change over time from 1995 to 2010. In contrast, the African CW became a much more important source of intra-CW imports (the region's share increased from $7 \%$ in 1995 to $18 \%$ in 2010) while the importance of the European region declined (down from a $20 \%$ share in 1995 to $11 \%$ in 2010).

Figure 4: Source of intra-CW goods imports by region (\% shares, $1995 \mathrm{v} 2010$ )
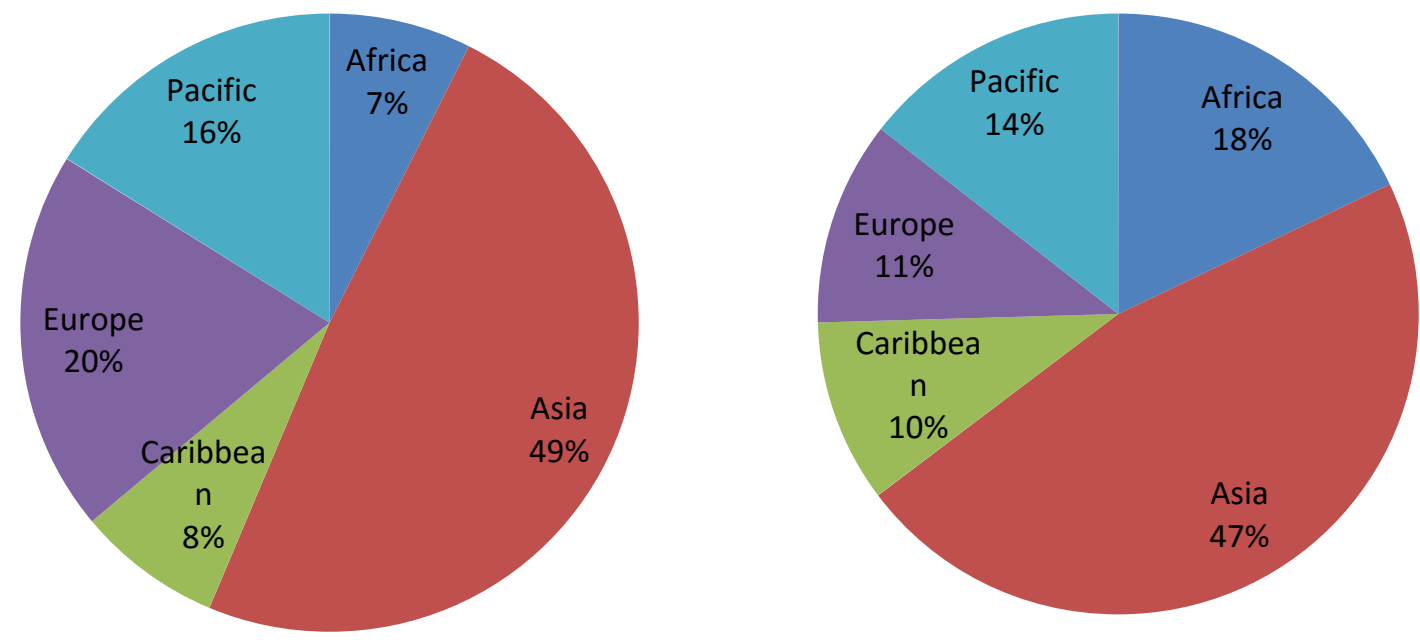

\begin{tabular}{lccccc|ccccc}
\hline & \multicolumn{4}{c}{ Imports (\% shares, 1995) } & \multicolumn{5}{c}{ Imports (\% shares, 2010) } \\
& Africa & Asia & Caribbean & Europe & Pacific & Africa & Asia & Caribbean & Europe & Pacific \\
\hline \hline Africa & 20.4 & 3.0 & 4.7 & 18.1 & 3.4 & 38.1 & 9.2 & 12.5 & 17.5 & 5.2 \\
Asia & 24.7 & 65.4 & 17.6 & 36.2 & 33.2 & 32.7 & 58.8 & 16.9 & 35.8 & 42.9 \\
Caribbean & 10.6 & 5.3 & 8.7 & 20.0 & 6.9 & 4.2 & 4.1 & 8.8 & 27.3 & 4.4 \\
Europe & 39.9 & 18.4 & 52.4 & 5.9 & 16.5 & 21.9 & 13.3 & 56.2 & 4.4 & 16.4 \\
Pacific & 4.4 & 7.9 & 16.6 & 19.9 & 39.9 & 3.1 & 14.7 & 5.5 & 14.9 & 31.1 \\
\hline \hline
\end{tabular}

Source: UN Comtrade; own calculations

The direction of intra-CW goods exports ( $\$ 382.5$ bn in 2010) is also primarily towards Asia (see Figure 5). More than 50\% of intra-CW goods exports in 1995 and close to 50\% in 2010 were destined to Asia. With the exception of the African region, the importance of other regions as a destination for intra-CW goods exports was almost stagnant over time from 1995 to 2010. The African CW became a much more important destination for intra-CW exports (the region's share increased from 9\% in 1995 to $16 \%$ in 2010). 
Figure 5: Destination of intra-CW goods exports by region (\% shares, $1995 \mathrm{v} 2010$ )
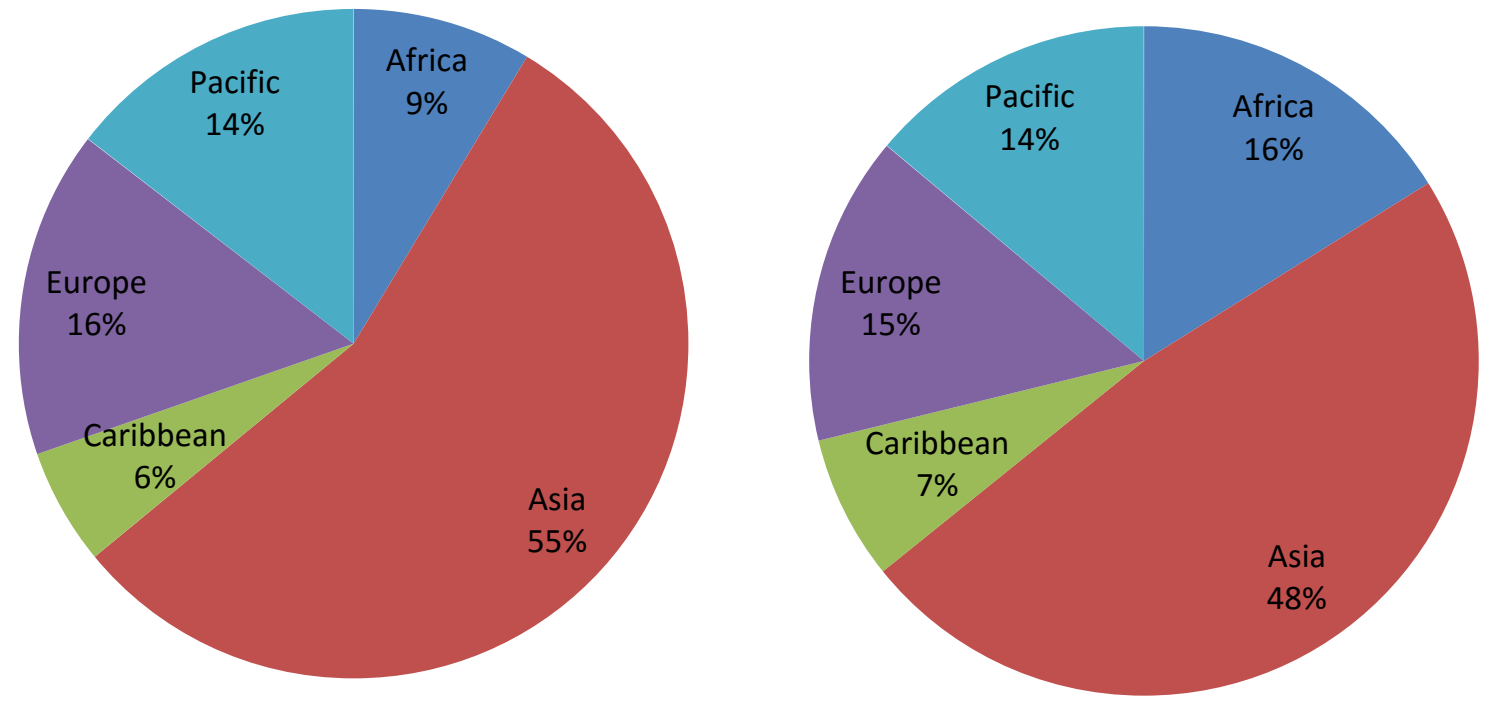

\begin{tabular}{lccccc|ccccc}
\hline & \multicolumn{4}{c}{ Exports (\% shares, 1995) } & \multicolumn{5}{c}{ Exports (\% shares, 2010) } \\
& Africa & Asia & Caribbean & Europe & Pacific & Africa & Asia & Caribbean & Europe & Pacific \\
\hline \hline Africa & 22.3 & 1.7 & 3.4 & 17.0 & 2.1 & 53.4 & 8.8 & 19.1 & 17.1 & 3.8 \\
Asia & 23.6 & 74.3 & 25.7 & 48.2 & 30.3 & 26.3 & 66.5 & 31.2 & 36.9 & 50.0 \\
Caribbean & 3.7 & 2.0 & 12.9 & 17.0 & 6.2 & 1.9 & 2.6 & 13.0 & 27.5 & 3.6 \\
Europe & 45.3 & 13.1 & 49.2 & 6.2 & 22.4 & 13.8 & 8.1 & 30.3 & 3.2 & 11.0 \\
Pacific & 5.0 & 8.8 & 8.7 & 11.7 & 39.1 & 4.6 & 13.9 & 6.4 & 15.3 & 31.7 \\
\hline \hline
\end{tabular}

Source: UN Comtrade; own calculations

Further breakdown of intra- and total CW merchandise trade by member state for 2000, 2010 is shown in Tables 1 and 2, for exports and imports, respectively. These tables reveal the following interesting stylized facts: (a) the smaller-trading CW countries such as Cameroon, Malawi, Mozambique, Namibia have registered a much greater growth in both imports and exports over 2000-10 than the larger-trading CW countries such as Canada, Singapore and the UK (b) This said, Bangladesh, Australia, Nigeria and India that are big CW traders have still shown remarkable growth exceeding 200\% in all cases except Australia over this period (c) The smaller $\mathrm{CW}$ members states rely much more on the rest of the $\mathrm{CW}$ as a trading partner than the rest of the world.

The CW is a more important destination for the exports of smaller CW members than the rest of the world. For instance, more than $90 \%$ of St. Vincent and Grenadines exports go to the CW. This is also generally true of most Caribbean and Pacific CW island states. While Ghana's exports to the world grew by $213 \%$, its exports to the CW grew by $580 \%$ over 2000 10. India's exports to the world grew more than 4 times and to the CW close to 5 times over 2000-10. Mozambique registered a 5 time increase in its exports, both to the world and to the CW, over 2000-10. In the case of Tanzania and Zambia, on the other hand, exports to the world grew much more (5 and 7 times, respectively) than exports to the CW (thrice and $72 \%$, respectively). Nigerian and Tanzanian imports from both the world and the CW grew more 
than 6.5 and 4 times, respectively, over this period. But the CW is not as important a source of their imports as the rest of the world.

Table 1: Breakdown of intra- and total CW goods exports by member ( $2000 \mathrm{v} 2010)$

\begin{tabular}{|c|c|c|c|c|c|c|c|c|}
\hline \multirow{2}{*}{$\begin{array}{l}\text { Commonwealth trade } \\
\text { (\$mn) } \\
\text { Members }\end{array}$} & \multicolumn{2}{|c|}{$\begin{array}{l}\text { Exports to } \\
\text { WLD }\end{array}$} & \multicolumn{2}{|c|}{ Exports to CW } & \multicolumn{2}{|c|}{$\begin{array}{l}\text { \% exports to } \\
\text { CW }\end{array}$} & \multicolumn{2}{|c|}{$\begin{array}{c}\text { Export growth }(\%, 2000- \\
10)\end{array}$} \\
\hline & 2000 & 2010 & 2000 & 2010 & 2000 & 2010 & to WLD & to $\mathrm{CW}$ \\
\hline Antigua and Barbuda & 3 & 2 & 2 & 1 & 67.6 & 60.8 & -19.7 & -27.8 \\
\hline Australia & 63766 & 206705 & 15369 & 44248 & 24.1 & 21.4 & 224.2 & 187.9 \\
\hline Bahamas, The & 244 & 304 & 18 & 66 & 7.6 & 21.8 & 24.3 & 257.6 \\
\hline Bangladesh & 5493 & 19231 & 766 & 3364 & 13.9 & 17.5 & 250.1 & 339.0 \\
\hline Barbados & 190 & 236 & 131 & 158 & 69.1 & 67.0 & 24.2 & 20.3 \\
\hline Belize & 186 & 282 & 60 & 91 & 32.3 & 32.4 & 52.0 & 52.5 \\
\hline Botswana & 2763 & 4693 & 2139 & 3336 & 77.4 & 71.1 & 69.9 & 56.0 \\
\hline Cameroon & 1823 & 3878 & 73 & 323 & 4.0 & 8.3 & 112.8 & 344.1 \\
\hline Canada & 277113 & 362147 & 6369 & 23560 & 2.3 & 6.5 & 30.7 & 269.9 \\
\hline Cyprus & 415 & 751 & 82 & 121 & 19.7 & 16.2 & 81.1 & 48.6 \\
\hline Dominica & 51 & 28 & 42 & 21 & 82.6 & 76.3 & -45.2 & -49.4 \\
\hline Fiji & 469 & 555 & 282 & 318 & 60.0 & 57.3 & 18.3 & 12.9 \\
\hline Ghana & 1671 & 5233 & 468 & 3187 & 28.0 & 60.9 & 213.2 & 581.1 \\
\hline Grenada & 71 & & 12 & & 16.6 & & & \\
\hline Guyana & 518 & 890 & 285 & 525 & 54.9 & 59.0 & 71.6 & 84.3 \\
\hline India & 42358 & 220408 & 7594 & 45213 & 17.9 & 20.5 & 420.3 & 495.4 \\
\hline Jamaica & 1268 & 1247 & 341 & 310 & 26.9 & 24.9 & -1.7 & -9.1 \\
\hline Kenya & 1571 & 5169 & 811 & 2321 & 51.6 & 44.9 & 229.0 & 186.3 \\
\hline Kiribati & & 4 & & 1 & & 28.5 & & \\
\hline Lesotho & 336 & & 93 & & 27.7 & & & \\
\hline Malawi & 370 & 1065 & 119 & 361 & 32.2 & 33.9 & 187.5 & 202.4 \\
\hline Malaysia & 98230 & 198791 & 28211 & 51359 & 28.7 & 25.8 & 102.4 & 82.1 \\
\hline Maldives & 76 & 74 & 23 & 25 & 30.2 & 33.2 & -2.6 & 7.2 \\
\hline Malta & 2222 & 3717 & 567 & 656 & 25.5 & 17.7 & 67.3 & 15.7 \\
\hline Mauritius & 1490 & 1490 & 485 & 561 & 32.6 & 37.7 & 0.0 & 15.7 \\
\hline Mozambique & 364 & 2197 & 92 & 536 & 25.4 & 24.4 & 503.5 & 479.6 \\
\hline Namibia & 1327 & 5848 & 833 & 2872 & 62.8 & 49.1 & 340.8 & 244.6 \\
\hline New Zealand & 12773 & 29704 & 4282 & 10960 & 33.5 & 36.9 & 132.6 & 155.9 \\
\hline Nigeria & 27079 & 86568 & 5359 & 21628 & 19.8 & 25.0 & 219.7 & 303.6 \\
\hline Pakistan & & 20989 & & 3564 & & 17.0 & & \\
\hline Papua New Guinea & 2407 & & 300 & & 12.5 & & & \\
\hline Samoa & & 60 & & 54 & & 90.8 & & \\
\hline Seychelles & 129 & & 64 & & 49.2 & & & \\
\hline Sierra Leone & 12 & & 1 & & 5.4 & & & \\
\hline Singapore & 137806 & 351867 & 39946 & 88884 & 29.0 & 25.3 & 155.3 & 122.5 \\
\hline Solomon Islands & & 208 & & 33 & & 15.9 & & \\
\hline South Africa & 26298 & 82626 & 6479 & 28063 & 24.6 & 34.0 & 214.2 & 333.1 \\
\hline Sri Lanka & 5203 & 8304 & 1069 & 2160 & 20.5 & 26.0 & 59.6 & 102.2 \\
\hline St. Kitts and Nevis & 29 & 27 & 8 & 2 & 27.1 & 8.7 & -8.1 & -70.4 \\
\hline St. Lucia & 39 & & 32 & & 82.4 & & & \\
\hline
\end{tabular}




\begin{tabular}{lcccccccc} 
St. Vincent and the & 43 & 35 & 40 & 32 & $\mathbf{9 2 . 4}$ & $\mathbf{9 2 . 2}$ & -19.9 & -20.1 \\
Grenadines & 891 & & 690 & & $\mathbf{7 7 . 4}$ & & & \\
Swaziland & 656 & 3922 & 332 & 1314 & $\mathbf{5 0 . 6}$ & $\mathbf{3 3 . 5}$ & $\mathbf{4 9 8 . 0}$ & $\mathbf{2 9 5 . 7}$ \\
Tanzania & 9 & 8 & 2 & 2 & 19.1 & 25.1 & -5.2 & 24.5 \\
Tonga & 4273 & 9992 & 1056 & 2306 & 24.7 & 23.1 & $\mathbf{1 3 3 . 8}$ & $\mathbf{1 1 8 . 4}$ \\
Trinidad and Tobago & 372 & 1152 & 158 & 394 & 42.6 & 34.2 & $\mathbf{2 1 0 . 0}$ & $\mathbf{1 4 8 . 9}$ \\
Uganda & $\mathbf{2 9 4 8 9 9}$ & $\mathbf{4 2 2 0 1 4}$ & $\mathbf{2 4 0 2 1}$ & $\mathbf{3 8 4 3 1}$ & 8.1 & 9.1 & 43.1 & 60.0 \\
United Kingdom & 23 & 46 & 13 & 19 & $\mathbf{5 4 . 6}$ & 41.1 & 98.8 & 49.7 \\
Vanuatu & 892 & 7200 & 628 & 1082 & $\mathbf{7 0 . 4}$ & 15.0 & $\mathbf{7 0 6 . 9}$ & 72.3 \\
Zambia & $\mathbf{2 2 6 2 7}$ & $\mathbf{4 9 2 7 8}$ & $\mathbf{3 3 2 8}$ & $\mathbf{9 1 0 6}$ & $\mathbf{3 7 . 0}$ & $\mathbf{3 5 . 0}$ & $\mathbf{1 4 1 . 9}$ & $\mathbf{1 4 7 . 2}$ \\
\hline \hline
\end{tabular}

Source: UN Comtrade; own calculations

Table 2: Breakdown of intra- and total CW goods imports by member ( $2000 \mathrm{v} 2010)$

\begin{tabular}{|c|c|c|c|c|c|c|c|c|}
\hline \multirow{2}{*}{$\begin{array}{l}\text { Commonwealth trade } \\
\text { (\$mn) } \\
\text { Members }\end{array}$} & \multicolumn{2}{|c|}{$\begin{array}{c}\text { Imports from } \\
\text { WLD }\end{array}$} & \multicolumn{2}{|c|}{$\begin{array}{c}\text { Imports from } \\
\text { CW }\end{array}$} & \multicolumn{2}{|c|}{$\begin{array}{c}\text { \% imports from } \\
\text { CW }\end{array}$} & \multicolumn{2}{|c|}{$\begin{array}{c}\text { Import growth }(\%, 2000- \\
10)\end{array}$} \\
\hline & 2000 & 2010 & 2000 & 2010 & 2000 & 2010 & from WLD & from CW \\
\hline Antigua and Barbuda & 338 & 501 & 82 & 73 & 24.1 & 14.5 & 48.2 & -10.9 \\
\hline Australia & 67478 & 187868 & 14733 & 38961 & 21.8 & 20.7 & 178.4 & 164.4 \\
\hline Bahamas, The & 2002 & 2862 & 48 & 102 & 2.4 & 3.6 & 42.9 & 113.0 \\
\hline Bangladesh & 7611 & 30504 & 2106 & 8954 & 27.7 & 29.4 & 300.8 & 325.1 \\
\hline Barbados & 1156 & 1196 & 393 & 291 & 34.0 & 24.3 & 3.5 & -26.1 \\
\hline Belize & 447 & 700 & 36 & 37 & 8.0 & 5.3 & 56.6 & 4.4 \\
\hline Botswana & 2072 & 5657 & 1647 & 4826 & 79.5 & 85.3 & 173.0 & 192.9 \\
\hline Cameroon & 1484 & 5115 & 388 & 1403 & 26.2 & 27.4 & 244.7 & 261.5 \\
\hline Canada & 240091 & 388270 & 15167 & 22701 & 6.3 & 5.8 & 61.7 & 49.7 \\
\hline Cyprus & 3845 & 8645 & 523 & 998 & 13.6 & 11.6 & 124.8 & 91.0 \\
\hline Dominica & 148 & 225 & 58 & 68 & 39.4 & 30.1 & 51.6 & 15.6 \\
\hline Fiji & & 1808 & & 1362 & & 75.3 & & \\
\hline Ghana & 2933 & 8057 & 892 & 1620 & 30.4 & 20.1 & 174.7 & 81.5 \\
\hline Grenada & 239 & & 90 & 502 & 37.5 & & & 460.3 \\
\hline Guyana & 573 & 1452 & 156 & 533 & 27.2 & 36.7 & 153.1 & 241.0 \\
\hline India & 52940 & 350029 & 9988 & 1085 & 18.9 & 0.3 & 561.2 & -89.1 \\
\hline Jamaica & 3192 & 5225 & 644 & 3836 & 20.2 & 73.4 & 63.7 & 496.1 \\
\hline Kenya & 2891 & 12093 & 866 & 53 & 29.9 & 0.4 & 318.2 & -93.9 \\
\hline Kiribati & & 73 & & & & 0.0 & & \\
\hline Lesotho & 613 & & 500 & & 81.6 & & & \\
\hline Malawi & 532 & 2173 & 347 & 1269 & 65.2 & 58.4 & 308.4 & 265.4 \\
\hline Malaysia & 81290 & 164466 & 16785 & 29411 & 20.6 & 17.9 & 102.3 & 75.2 \\
\hline Maldives & 389 & 1095 & 266 & 605 & 68.3 & 55.2 & 181.8 & 127.7 \\
\hline Malta & 3399 & 5732 & 850 & 1114 & 25.0 & 19.4 & 68.7 & 31.1 \\
\hline Mauritius & 2081 & 4402 & 822 & 1948 & 39.5 & 44.2 & 111.5 & 137.0 \\
\hline Mozambique & 1162 & 3561 & 551 & 1736 & 47.4 & 48.8 & 206.4 & 215.2 \\
\hline Namibia & 1435 & 5980 & 1290 & 4930 & 89.9 & 82.5 & 316.7 & 282.1 \\
\hline New Zealand & 13904 & 30158 & 4685 & 9783 & 33.7 & 32.4 & 116.9 & 108.8 \\
\hline Nigeria & 5817 & 44235 & 1210 & 9446 & 20.8 & 21.4 & 660.5 & 680.6 \\
\hline
\end{tabular}




\begin{tabular}{|c|c|c|c|c|c|c|c|c|}
\hline Pakistan & & 37513 & & 7017 & & 18.7 & & \\
\hline Papua New Guinea & 1035 & & 717 & & 69.3 & & & \\
\hline Samoa & & 310 & & 209 & & 67.5 & & \\
\hline Seychelles & 342 & & 133 & & 38.9 & & & \\
\hline Sierra Leone & 152 & & 23 & & 15.2 & & & \\
\hline Singapore & 134546 & 310791 & 30886 & 58168 & 23.0 & 18.7 & 131.0 & 88.3 \\
\hline Solomon Islands & & 328 & & 248 & & 75.7 & & \\
\hline South Africa & 26771 & 82663 & 4393 & 15893 & 16.4 & 19.2 & 208.8 & 261.7 \\
\hline Sri Lanka & 6178 & 12354 & 2010 & 5682 & 32.5 & 46.0 & 100.0 & 182.6 \\
\hline St. Kitts and Nevis & 196 & 270 & 64 & 46 & 32.8 & 17.2 & 37.9 & -27.9 \\
\hline St. Lucia & 355 & & 127 & & 35.9 & & & \\
\hline $\begin{array}{l}\text { St. Vincent and the } \\
\text { Grenadines }\end{array}$ & 162 & 379 & 70 & 177 & 43.2 & 46.8 & 134.9 & 154.2 \\
\hline Swaziland & 1099 & & 1037 & & 94.4 & & & \\
\hline Tanzania & 1586 & 8013 & 599 & 3086 & 37.7 & 38.5 & 405.1 & 415.4 \\
\hline Tonga & 69 & 159 & 55 & 116 & 79.0 & 72.8 & 128.6 & 110.9 \\
\hline Trinidad and Tobago & 3308 & 6479 & 355 & 818 & 10.7 & 12.6 & 95.9 & 130.3 \\
\hline Uganda & 954 & 4664 & 567 & 1928 & 59.4 & 41.3 & 389.0 & 240.0 \\
\hline United Kingdom & 370240 & 624118 & 35023 & 64813 & 9.5 & 10.4 & 68.6 & 85.1 \\
\hline Vanuatu & 87 & 276 & 61 & 195 & 70.5 & 70.5 & 218.4 & 218.6 \\
\hline Zambia & 888 & 5321 & 643 & 2385 & 72.4 & 44.8 & 499.2 & 270.7 \\
\hline Average & 23819 & 56327 & 3452 & 7343 & 38.2 & 34.4 & 190.5 & 166.6 \\
\hline
\end{tabular}

Source: UN Comtrade; own calculations

The composition of intra-CW average goods trade in 2010 reveals that the top ten traded intra-CW products accounted for $67 \%$ of intra-CW trade in that year. But just one product (mineral fuels and oils, HS2 code 27) comprised nearly 25\% of intra-CW trade in 2010, suggesting a concentrated trade and production structure (see Figure 6).

The trade composition of the Asian, European and Pacific CW regions is even more concentrated with just one product accounting for $30 \%$ of average regional intra-CW trade and the top ten traded products accounting for nearly $75 \%$ (see Table 3). With the exception of CW Europe, mineral fuels and oils (HS2 code 27) is the most traded intra-CW product. In the case of CW Europe, miscellaneous goods (HS2 product code 99) are the most traded product. 
Figure 6: Composition of intra-CW average goods trade (\% shares, 2010)

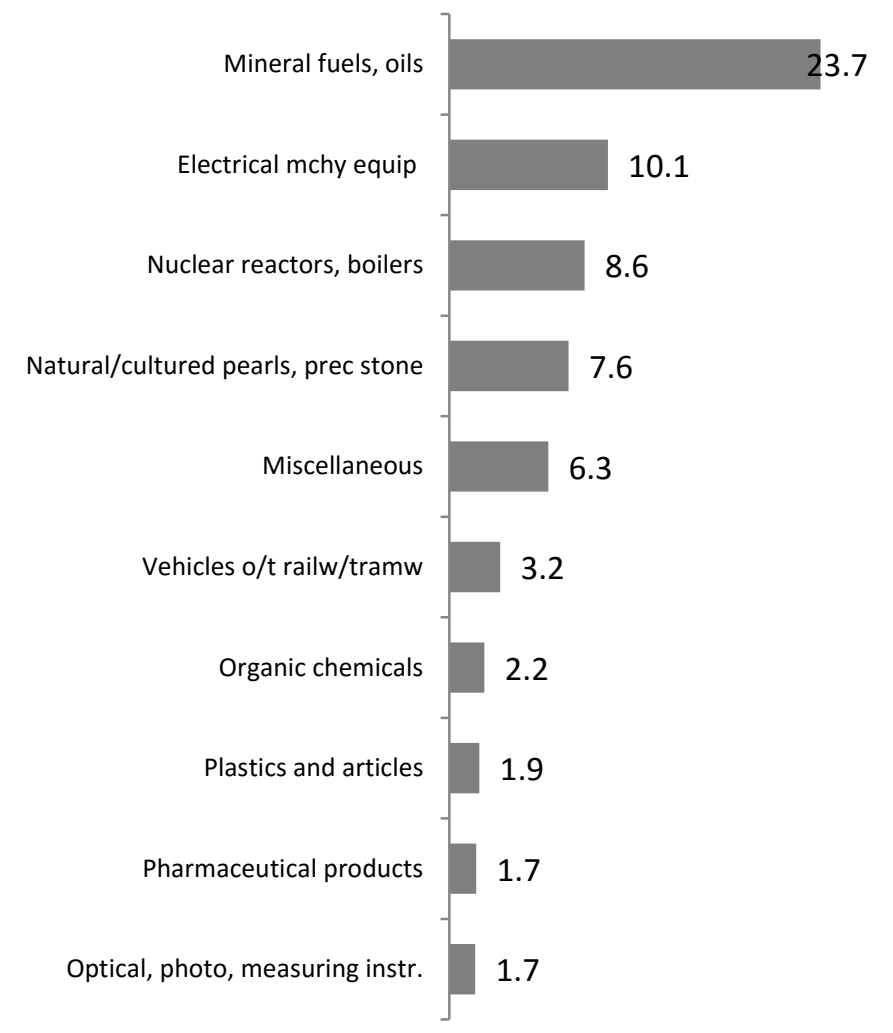


Table 3: Composition of intra-CW average goods trade by region (\% shares, 2010)

\begin{tabular}{|c|c|c|c|c|c|c|c|c|c|}
\hline Africa & $\begin{array}{c}\% \\
\text { shares } \\
\end{array}$ & Products & $\begin{array}{c}\% \\
\text { shares }\end{array}$ & Caribbean & $\begin{array}{c}\% \\
\text { shares }\end{array}$ & Products & $\begin{array}{c}\% \\
\text { shares } \\
\end{array}$ & Products & $\begin{array}{c}\% \\
\text { shares } \\
\end{array}$ \\
\hline Mineral fuels, oils & 19.7 & Mineral fuels, oils & 29.8 & Mineral fuels, oils & 25.4 & \multirow{2}{*}{$\begin{array}{l}\text { Miscellaneous } \\
\text { Natural/cultured pearls, prec } \\
\text { stone }\end{array}$} & 30.2 & Mineral fuels, oils & 30.2 \\
\hline Nuclear reactors, boilers & 10.6 & Electrical mchy equip & 14.8 & Nuclear reactors, boilers & 10.4 & & 12.1 & \multirow{2}{*}{$\begin{array}{l}\text { Nuclear reactors, boilers } \\
\text { Natural/cultured pearls, prec } \\
\text { stone }\end{array}$} & 8.8 \\
\hline Vehicles o/t railw/tramw & 9.4 & Nuclear reactors, boilers & 9.1 & Electrical mchy equip & 7.6 & Mineral fuels, oils & 6.5 & & 8.3 \\
\hline Electrical mchy equip & 7.2 & $\begin{array}{l}\text { Natural/cultured pearls, prec } \\
\text { stone }\end{array}$ & 7.8 & $\begin{array}{l}\text { Natural/cultured pearls, prec } \\
\text { stone }\end{array}$ & 6.4 & \multirow{2}{*}{$\begin{array}{l}\text { Nuclear reactors, boilers } \\
\text { Art of apparel \& clothing } \\
\text { access }\end{array}$} & 5.2 & Electrical mchy equip & 7.7 \\
\hline Articles of iron or steel & 3.2 & Animal/veg fats \& oils & 2.3 & Pharmaceutical products & 4.9 & & 4.6 & Vehicles o/t railw/tramw & 3.8 \\
\hline Pharmaceutical products & 3.0 & Organic chemicals & 2.2 & Organic chemicals & 2.9 & Electrical mchy equip & 4.1 & Pharmaceutical products & 3.4 \\
\hline Iron and steel & 2.9 & Plastics and articles & 2.2 & Vehicles o/t railw/tramw & 2.9 & Other art of apparel \& clothing & 4.1 & $\begin{array}{l}\text { Optical, photo, measuring } \\
\text { instr. }\end{array}$ & 2.2 \\
\hline Plastics and articles & 2.7 & Iron and steel & 1.9 & Beverages, spirits and vinegar & 2.9 & Organic chemicals & 3.5 & Plastics and articles & 2.1 \\
\hline Animal/veg fats \& oils & 2.2 & Cotton & 1.7 & $\begin{array}{l}\text { Inorgn chem; compds of prec } \\
\mathrm{mtl}\end{array}$ & 2.7 & Vehicles o/t railw/tramw & 2.4 & Miscellaneous & 1.9 \\
\hline $\begin{array}{l}\text { Inorgn chem; compds of prec } \\
\text { mtl }\end{array}$ & 1.9 & $\begin{array}{l}\text { Optical, photo, measuring } \\
\text { instr. }\end{array}$ & 1.6 & $\begin{array}{l}\text { Optical, photo, measuring } \\
\text { instr. }\end{array}$ & 2.5 & Beverages, spirits and vinegar & 2.2 & Paper \& pulp & 1.8 \\
\hline
\end{tabular}

Source: UN Comtrade; own calculations 


\subsection{Trade in services}

Commonwealth services trade with the world (forecast ${ }^{5}$ at $\$ 1.3$ tr in 2015) as a share of global services trade (forecast at $\$ 7.4$ tr in 2015) increased slightly from $16.4 \%$ in 1995 to $16.9 \%$ in 2009 (and is further projected to rise to $17.5 \%$ in 2015); world services trade more than tripled from $\$ 1.25$ tr in 1995 to $\$ 4.1$ tr in 2009. Significantly, intra-CW services trade (\$ 89.8 bn in 2009 and projected to rise to $\$ 265.6$ bn in 2015) as a share of commonwealth services trade with the world increased more than three times from $4 \%$ in 1995 to $13 \%$ in 2009. This share is further expected to rise to $20.5 \%$ in 2015 suggesting that trade in services amongst CW countries will become an even more important part of the CW's total services trade. Even as a share of global services trade, intra-CW services trade is likely to go up to $3.6 \%$ in 2015 from $1.9 \%$ in 2000 . While the projections for intra-CW services trade seem large, these are consistent with the average annual 20\% growth that intra-CW services trade has witnessed over 1995-2009; intra-CW services trade grew 9.6 times over this period, compared to the 1.6 times rise for intra-CW goods trade.

\section{Figure 7: World, commonwealth and intra-CW average services trade over time}

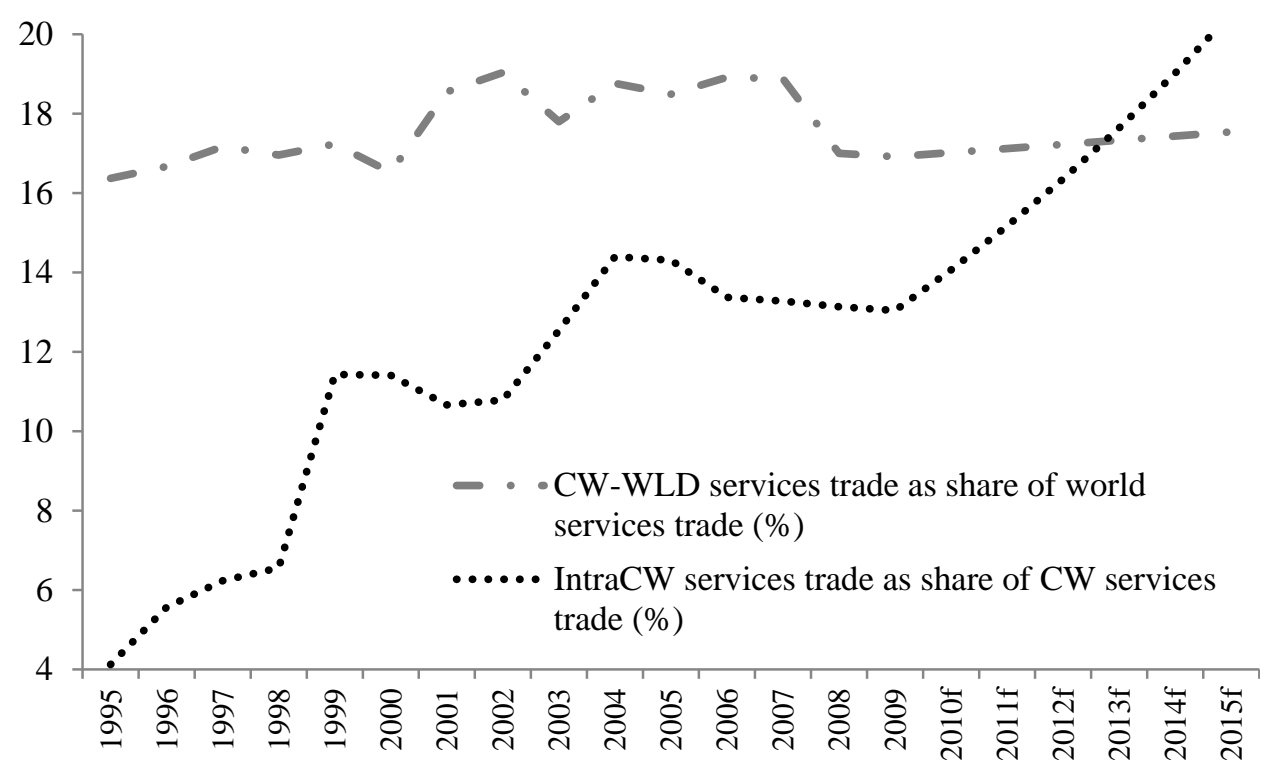

Source: Francois \& Pindyuk (2013); own calculations

The direction of the commonwealth's global services trade also reveals a very concentrated distribution (see Figure 8). The top $4 \mathrm{CW}$ countries contribute more than $75 \%$ of the commonwealth's global services trade; the top 10 accounted for more than $95 \%$ in 2009 . The UK is the most dominant CW services trader accounting for more than $40 \%$ of the commonwealth's global services trade. Nine of the top ten CW services traders figured in the top 10 list both in 2000 and 2009. India became even more important in 2009, while Canada was less important compared to its relative position in 2000.

\footnotetext{
${ }^{5}$ The forecasts made in this study for services trade fit exponential functions to services trade values over 19952009 to project future services trade values.
} 
Figure 8: Direction of commonwealth average services trade (\% shares, $2000 \mathrm{v} 2009$ )

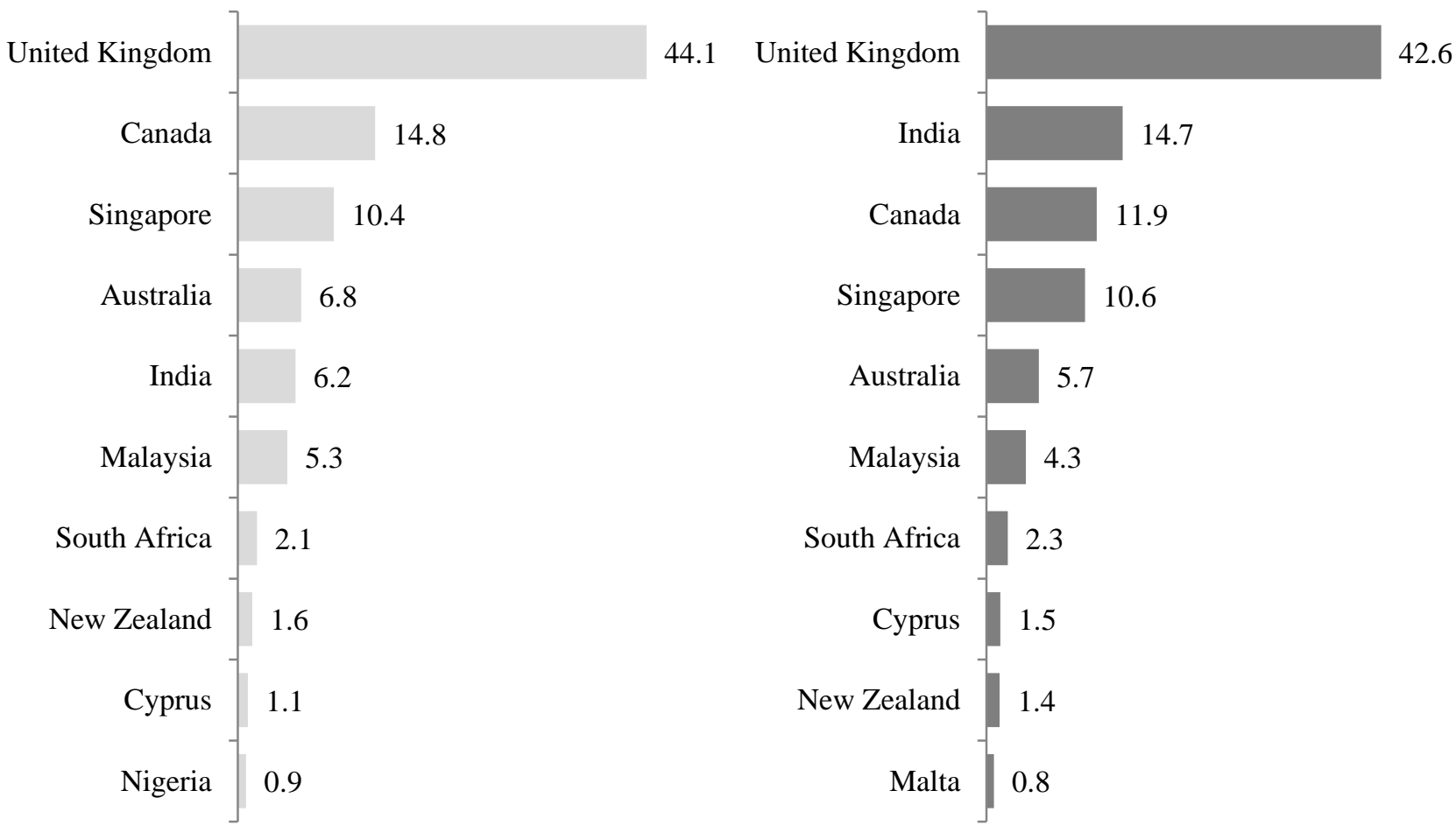

The geographical distribution of intra-CW services trade mirrors that of $\mathrm{CW}$ global services trade (see Figure 9). The top 4 countries contribute more than $70 \%$ of intra-CW services trade; the top 10 account for more than $95 \%$. The UK is the most dominant intra-CW services trader as well accounting for nearly one-third of intra-CW services trade. Nine of the top ten intra-CW services traders figured in the top 10 list both in 2000 and 2009. While India and Singapore became more important in 2009, Australia and Canada were less important compared to their relative positions in 2000.

Figure 9: Direction of intra-CW average services trade (\% shares, 2000 v 2009)

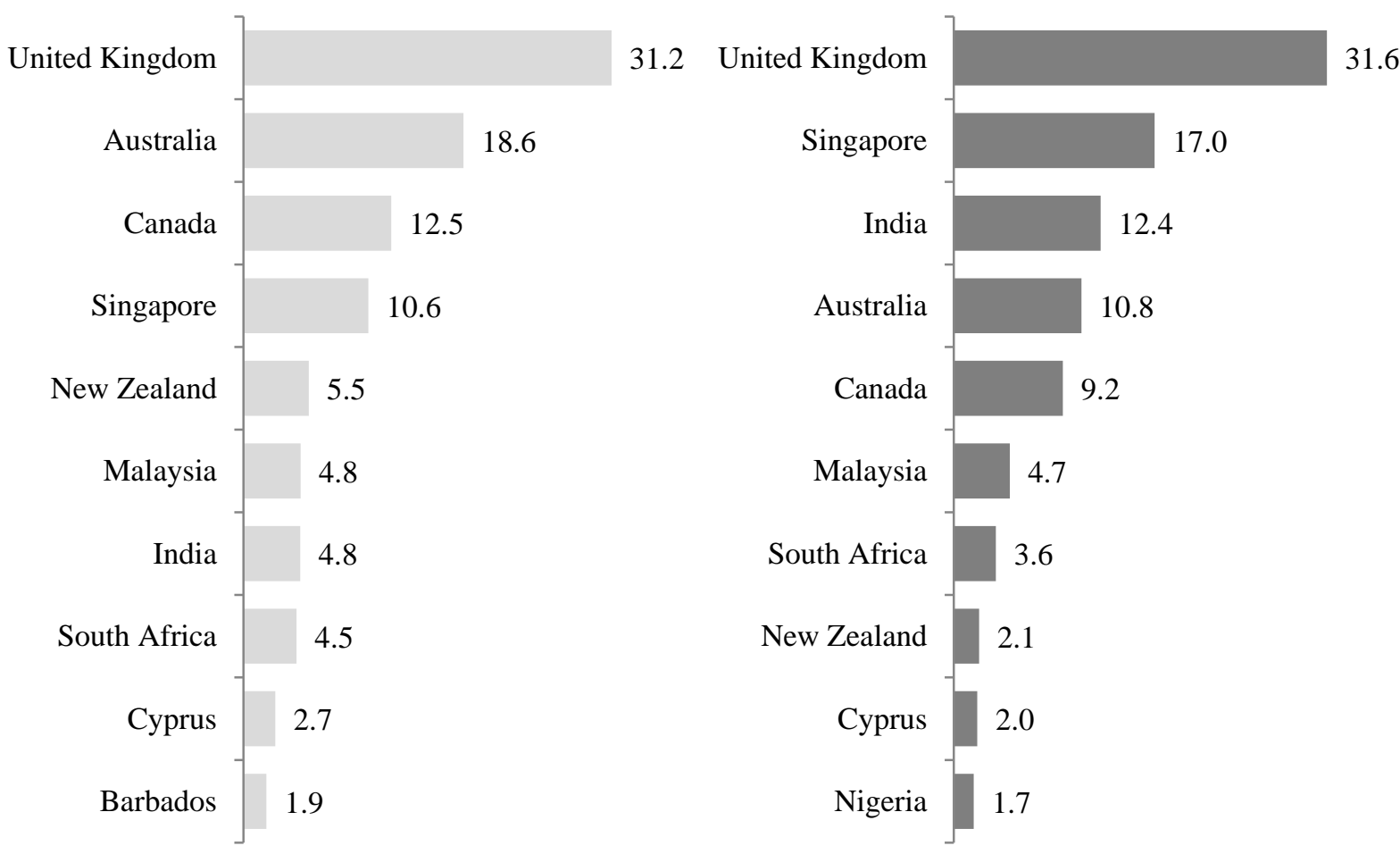


The direction of intra-CW services trade ( $\$ 89.8$ bn in 2009) by region witnessed significant changes over 2000-09 (see Figures 10 and 11). The importance of CW Asia both as a source (up 35\% in 2009 from 19\% in 2000) and destination (up 36\% in 2009 from 21\% in 2000) region increased while that of CW Pacific declined significantly (down 8\% in 2009 from 25\% in 2000 as a source of imports and down 18\% in 2009 from 26\% in 2000 as a destination of exports). The importance of CW Caribbean has declined as well over time. CW Europe has become a more important source of intra-CW services imports (up 42\% in 2009 from 36\% in 2000) but a less important destination for intra-CW services exports (down 27\% in 2009 from $33 \%$ in 2000).

Figure 10: Source of intra-CW services imports by region (\% shares, $2000 \mathrm{v} 2009$ )
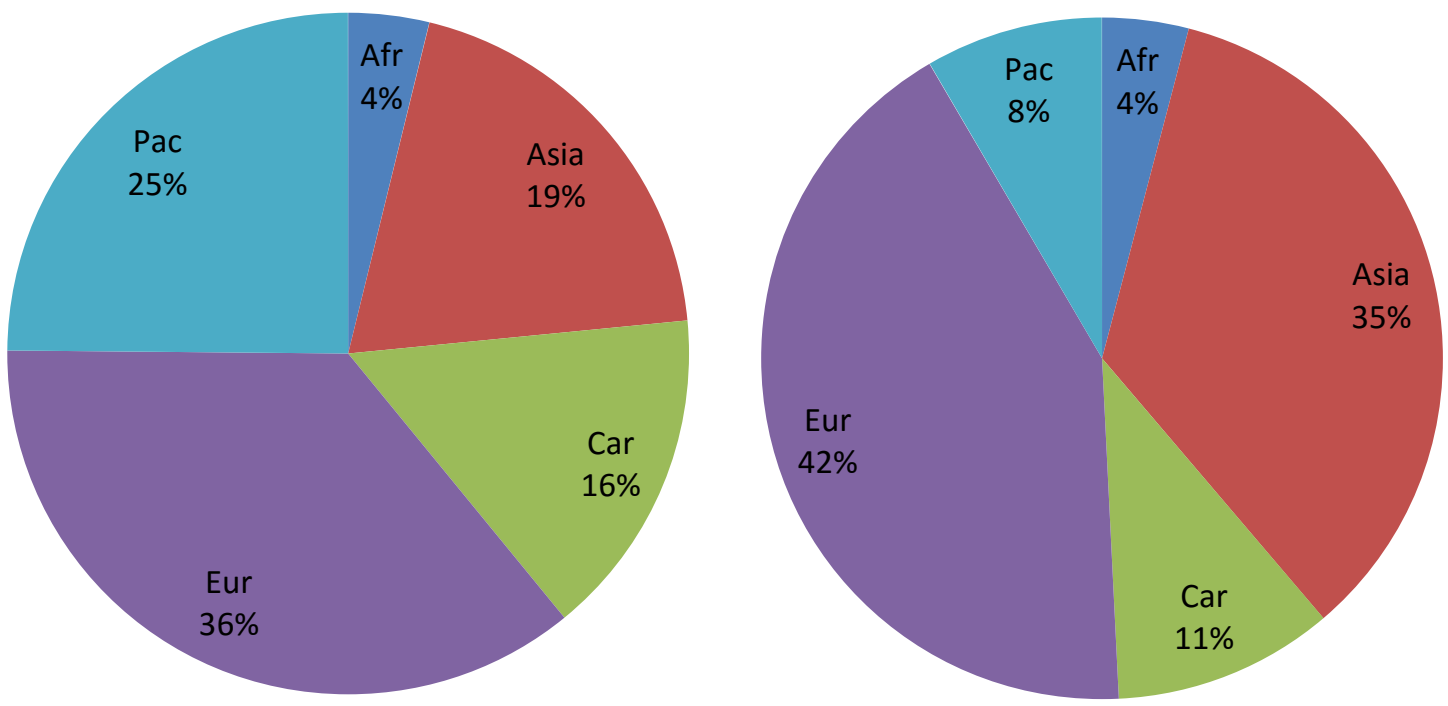

\begin{tabular}{lccccc|ccccc}
\hline & \multicolumn{4}{c|}{ Imports (\% shares, 2000) } & \multicolumn{5}{c}{ Imports (\% shares, 2009) } \\
& Africa & Asia & Caribbean & Europe & Pacific & Africa & Asia & Caribbean & Europe & Pacific \\
\hline \hline Africa & 9.6 & 0.0 & 1.5 & 8.4 & 1.1 & 1.4 & 2.4 & 1.3 & 10.6 & 0.5 \\
Asia & 0.0 & 22.2 & 7.3 & 24.3 & 22.7 & 11.7 & 41.8 & 15.5 & 36.7 & 39.0 \\
Caribbean & 6.4 & 7.8 & 33.8 & 22.1 & 5.8 & 4.9 & 4.8 & 13.0 & 19.6 & 9.0 \\
Europe & 77.4 & 42.2 & 49.8 & 20.6 & 34.0 & 80.6 & 43.2 & 65.7 & 18.2 & 46.1 \\
Pacific & 6.7 & 27.8 & 7.6 & 24.6 & 36.4 & 1.5 & 7.8 & 4.5 & 14.9 & 5.4 \\
\hline \hline
\end{tabular}


Figure 11: Destination of intra-CW services exports by region (\% shares, $2000 \mathrm{v} 2009)$
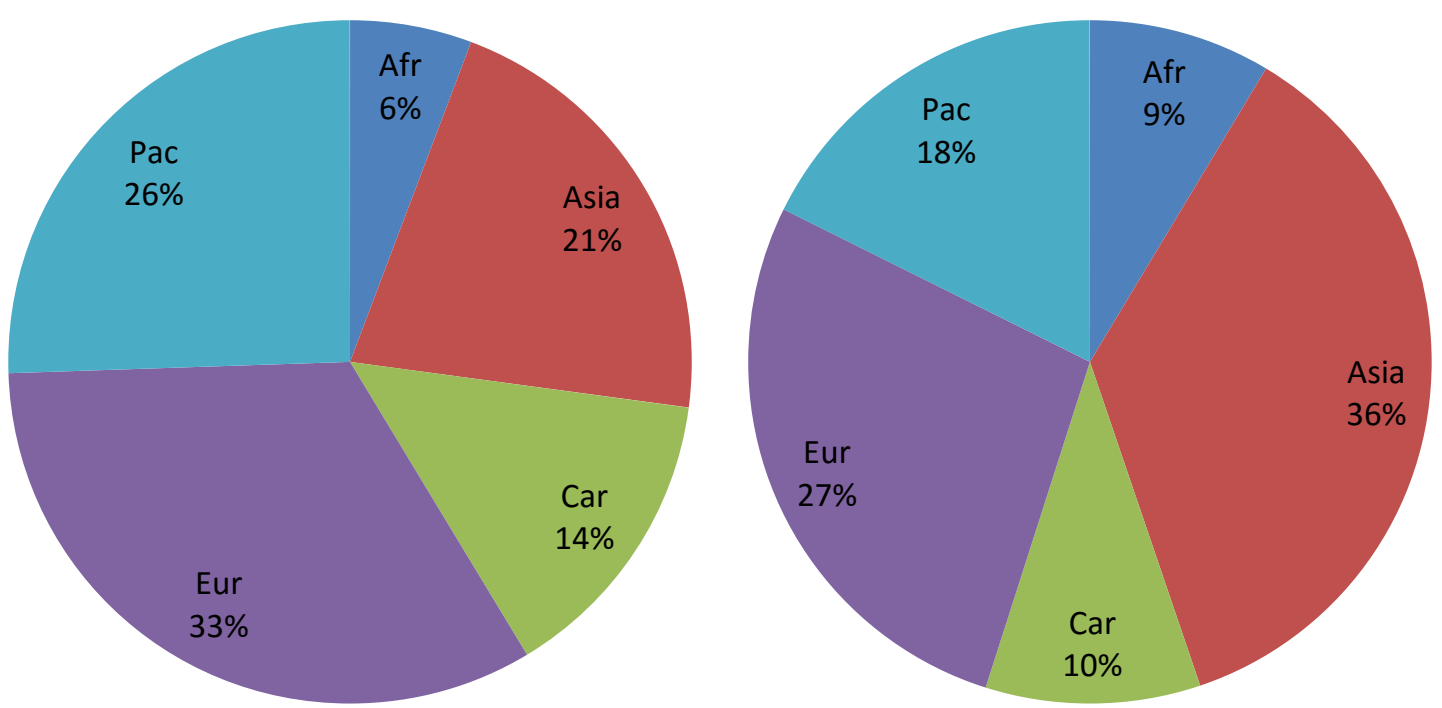

\begin{tabular}{lccccc|ccccc}
\hline & \multicolumn{4}{c}{ Exports (\% shares, 2000) } & \multicolumn{5}{c}{ Exports (\% shares, 2009) } \\
& Africa & Asia & Caribbean & Europe & Pacific & Africa & Asia & Caribbean & Europe & Pacific \\
\hline \hline Africa & 14.4 & 0.0 & 2.3 & 12.4 & 1.5 & 2.9 & 2.9 & 4.0 & 16.4 & 1.6 \\
Asia & 0.0 & 24.2 & 10.7 & 25.0 & 23.9 & 21.1 & 43.7 & 16.6 & 36.9 & 33.3 \\
Caribbean & 5.6 & 5.3 & 30.7 & 19.6 & 4.3 & 3.2 & 4.5 & 12.7 & 15.7 & 5.4 \\
Europe & 72.9 & 40.9 & 46.8 & 18.9 & 32.8 & 70.6 & 29.0 & 51.6 & 11.8 & 48.6 \\
Pacific & 7.1 & 29.6 & 9.4 & 24.1 & 37.4 & 2.2 & 19.9 & 15.2 & 19.2 & 11.2 \\
\hline \hline
\end{tabular}

Source: Francois \& Pindyuk (2013); own calculations

Further breakdown of intra- and total CW services trade by member state for 2000, 2009 is shown in Tables 4 and 5, for exports and imports, respectively. These tables suggest that the small island states are more reliant on the $\mathrm{CW}$ for their goods trade than for their services trade. Only Barbados (81\%, 2009), Solomon Islands (87.2\%) and Tonga (98.2\%) had more than $75 \%$ of their total services exports destined to the CW for instance. Most of the top CW services exporters showed more than $100 \%$ growth in services exports to both the CW and ROW over 2000-09. This growth was exceptional for India (380\% and 714\%, respectively) in particular. At the same time, Bangladesh (515 times) and Nigeria (155 times) registered phenomenal growth in services exports to the CW over this period.

India is not only a major services exporter but also a major services importer; its imports from the world and CW increased close to 6 and 5 times, respectively, over 2000-09. Other rapidly growing services importers included Brunei (services imports from the world and CW increased 71 and 10 times, respectively, over 2000-09), Nigeria (services imports from the CW rose 230 times over 2000-09) and Samoa (services imports from the world increased more than 450 times over this period). 
Table 4: Breakdown of intra- and total CW services exports by member (2000 v 2009)

\begin{tabular}{|c|c|c|c|c|c|c|c|c|}
\hline \multirow{2}{*}{$\begin{array}{l}\text { Commonwealth trade } \\
\text { (\$mn) } \\
\text { Member }\end{array}$} & \multicolumn{2}{|c|}{ Exports to WLD } & \multicolumn{2}{|c|}{ Exports to CW } & \multicolumn{2}{|c|}{$\begin{array}{l}\text { \% exports to } \\
\text { CW }\end{array}$} & \multicolumn{2}{|c|}{$\begin{array}{c}\text { Export growth }(\%, 2000 \\
09)\end{array}$} \\
\hline & 2000 & 2009 & 2000 & 2009 & 2000 & 2009 & to WLD & to $\mathbf{C W}$ \\
\hline Antigua and Barbuda & 170.3 & 98.9 & & 6.3 & & 6.3 & -41.9 & \\
\hline Australia & 19493.7 & 47152.4 & 6015.6 & 13615.5 & 30.9 & 28.9 & 141.9 & 126.3 \\
\hline Bahamas, The & 1026.5 & 925.0 & 22.9 & 336.8 & 2.2 & 36.4 & -9.9 & 1371.8 \\
\hline Bangladesh & 1623.4 & 582.4 & 0.5 & 264.8 & 0.0 & 45.5 & -64.1 & 51517.2 \\
\hline Barbados & 718.2 & 1202.1 & 475.8 & 973.9 & 66.3 & 81.0 & 67.4 & 104.7 \\
\hline Belize & 123.0 & 184.0 & & 23.4 & & 12.7 & 49.6 & \\
\hline Botswana & 549.6 & 3.2 & & 1.1 & & 34.2 & -99.4 & \\
\hline Brunei Darussalam & 80.7 & 1420.6 & 75.7 & 399.7 & 93.8 & 28.1 & 1659.5 & 427.7 \\
\hline Cameroon & 958.0 & 534.7 & & 164.5 & & 30.8 & -44.2 & \\
\hline Canada & 44795.3 & 87896.9 & 4105.2 & 7208.7 & 9.2 & 8.2 & 96.2 & 75.6 \\
\hline Cyprus & 1728.8 & 8703.7 & 223.8 & 1059.4 & 12.9 & 12.2 & 403.5 & 373.4 \\
\hline Dominica & 59.6 & 38.2 & & 1.5 & & 4.0 & -36.0 & \\
\hline Fiji & 334.4 & 25.3 & 118.9 & 14.1 & 35.6 & 55.8 & -92.4 & -88.2 \\
\hline Ghana & 584.1 & 976.1 & & 504.2 & & 51.7 & 67.1 & \\
\hline Grenada & 107.1 & 39.9 & & 4.7 & & 11.9 & -62.7 & \\
\hline Guyana & 194.4 & 124.3 & & 56.4 & & 45.3 & -36.1 & \\
\hline India & 19287.9 & 92670.0 & 1767.6 & 14392.6 & 9.2 & 15.5 & 380.5 & 714.3 \\
\hline Jamaica & 1423.2 & 377.3 & 35.7 & 148.1 & 2.5 & 39.3 & -73.5 & 315.1 \\
\hline Kenya & 720.3 & 890.9 & & 273.2 & & 30.7 & 23.7 & \\
\hline Kiribati & 0.0 & 4.7 & & 4.7 & & 100.0 & & \\
\hline Lesotho & 43.4 & 26.3 & & 12.6 & & 47.8 & -39.4 & \\
\hline Malawi & 167.3 & 97.2 & & 45.7 & & 47.0 & -41.9 & \\
\hline Malaysia & 16748.7 & 21604.1 & 2211.0 & 6737.9 & 13.2 & 31.2 & 29.0 & 204.7 \\
\hline Maldives & 110.4 & 38.9 & & 17.2 & & 44.2 & -64.8 & \\
\hline Malta & 905.3 & 4450.1 & 86.6 & 914.6 & 9.6 & 20.6 & 391.6 & 956.5 \\
\hline Mauritius & 763.6 & 646.1 & & 248.2 & & 38.4 & -15.4 & \\
\hline Mozambique & 447.0 & 424.6 & & 131.6 & & 31.0 & -5.0 & \\
\hline Namibia & 334.0 & 130.9 & & 40.7 & & 31.1 & -60.8 & \\
\hline Nauru & 0.0 & 0.1 & & & & & & \\
\hline New Zealand & 4555.9 & 7337.0 & 2031.3 & 2053.3 & 44.6 & 28.0 & 61.0 & 1.1 \\
\hline Nigeria & 3302.0 & 5810.9 & 13.5 & 2101.2 & 0.4 & 36.2 & 76.0 & 15509.3 \\
\hline Pakistan & 2252.0 & 1467.6 & 73.4 & 656.0 & 3.3 & 44.7 & -34.8 & 794.3 \\
\hline Papua New Guinea & 870.2 & 216.0 & 242.7 & 130.0 & 27.9 & 60.2 & -75.2 & -46.4 \\
\hline Rwanda & 201.2 & 70.6 & & 11.0 & & 15.6 & -64.9 & \\
\hline Samoa & 3.2 & 9.2 & 3.2 & 0.0 & 100.0 & 0.0 & 190.6 & -100.0 \\
\hline Seychelles & 190.6 & 181.8 & & 50.4 & & 27.7 & -4.7 & \\
\hline Sierra Leone & 113.0 & 1416.7 & & 73.7 & & 5.2 & 1153.7 & \\
\hline Singapore & 30982.8 & 51705.6 & 2916.5 & 9862.6 & 9.4 & 19.1 & 66.9 & 238.2 \\
\hline Solomon Islands & 72.6 & 10.9 & & 9.5 & & 87.2 & -85.0 & \\
\hline South Africa & 6433.1 & 13944.3 & 1882.4 & 3753.6 & 29.3 & 26.9 & 116.8 & 99.4 \\
\hline Sri Lanka & 1622.3 & 366.5 & & 131.0 & & 35.7 & -77.4 & \\
\hline St. Kitts and Nevis & 80.7 & 104.9 & & 4.7 & & 4.5 & 30.0 & \\
\hline St. Lucia & 139.5 & 28.3 & & 4.7 & & 16.7 & -79.7 & \\
\hline $\begin{array}{l}\text { St. Vincent and the } \\
\text { Grenadines }\end{array}$ & 61.6 & 56.2 & & 4.7 & & 8.4 & -8.9 & \\
\hline
\end{tabular}




\begin{tabular}{lcccccccc} 
Swaziland & 417.2 & 76.6 & 0.0 & 45.8 & 0.0 & $\mathbf{5 9 . 7}$ & -81.6 & \\
Tanzania & 684.3 & 388.0 & & 83.2 & & 21.4 & -43.3 & \\
Tonga & 0.0 & 8.0 & & 7.8 & & $\mathbf{9 8 . 2}$ & & \\
Trinidad and Tobago & 388.2 & 643.1 & 39.0 & 337.4 & 10.1 & $\mathbf{5 2 . 5}$ & 65.7 & $\mathbf{7 6 4 . 2}$ \\
Tuvalu & 0.0 & 2.1 & & 0.2 & & 9.2 & & \\
Uganda & 459.2 & 344.9 & & 112.7 & & 32.7 & -24.9 & \\
United Kingdom & $\mathbf{1 1 5 4 1 1 . 0}$ & $\mathbf{2 7 8 5 6 3 . 0}$ & $\mathbf{1 0 5 9 7 . 6}$ & $\mathbf{2 2 6 4 3 . 8}$ & 9.2 & 8.1 & $\mathbf{1 4 1 . 4}$ & $\mathbf{1 1 3 . 7}$ \\
Vanuatu & 70.2 & 9.9 & & 1.5 & & 15.5 & -85.9 & \\
Zambia & 355.0 & 149.7 & & 72.4 & & $\mathbf{4 8 . 3}$ & $\mathbf{- 5 7 . 8}$ & \\
\hline \hline Average & $\mathbf{5 3 2 3 . 8}$ & $\mathbf{1 1 9 6 5 . 7}$ & $\mathbf{1 4 9 7 . 2}$ & $\mathbf{1 7 2 6 . 0}$ & $\mathbf{2 3 . 6}$ & $\mathbf{3 3 . 3}$ & $\mathbf{7 5 . 5}$ & $\mathbf{3 4 9 8 . 7}$ \\
\hline \hline
\end{tabular}

Source: Francois \& Pindyuk (2013); own calculations

Table 5: Breakdown of intra- \& total CW services imports by member ( $2000 \mathrm{v} 2009$ )

\begin{tabular}{|c|c|c|c|c|c|c|c|c|}
\hline \multirow{2}{*}{$\begin{array}{l}\text { Commonwealth trade } \\
\text { (\$mn) } \\
\text { Member }\end{array}$} & \multicolumn{2}{|c|}{ Imports from WLD } & \multicolumn{2}{|c|}{$\begin{array}{c}\text { Imports from } \\
\text { CW }\end{array}$} & \multicolumn{2}{|c|}{$\begin{array}{l}\% \text { imports from } \\
\text { CW }\end{array}$} & \multicolumn{2}{|c|}{$\begin{array}{c}\text { Import growth }(\%, 2000- \\
09)\end{array}$} \\
\hline & 2000 & 2009 & 2000 & 2009 & 2000 & 2009 & from WLD & from $\mathrm{CW}$ \\
\hline Antigua and Barbuda & 432.8 & 517.2 & 1.7 & 0.0 & 0.4 & 0.0 & 19.5 & -100.0 \\
\hline Australia & 19939.0 & 30620.1 & 6262.7 & 5779.8 & 31.4 & 18.9 & 53.6 & -7.7 \\
\hline Bahamas, The & 1973.4 & 2266.1 & 72.0 & 0.0 & 3.7 & 0.0 & 14.8 & -100.0 \\
\hline Bangladesh & 816.1 & 1957.0 & 0.2 & 0.0 & 0.0 & 0.0 & 139.8 & -100.0 \\
\hline Barbados & 1508.9 & 1464.0 & 799.9 & 0.0 & 53.0 & 0.0 & -3.0 & -100.0 \\
\hline Belize & 153.4 & 344.4 & & 0.0 & 0.0 & 0.0 & 124.5 & \\
\hline Botswana & 325.8 & 312.4 & & 0.0 & 0.0 & 0.0 & -4.1 & \\
\hline Brunei Darussalam & 18.0 & 1288.7 & 18.0 & 198.7 & 100.0 & 15.4 & 7068.3 & 1005.2 \\
\hline Cameroon & 591.2 & 1234.2 & & 0.0 & 0.0 & 0.0 & 108.7 & \\
\hline Canada & 40751.8 & 76033.2 & 4139.9 & 9371.0 & 10.2 & 12.3 & 86.6 & 126.4 \\
\hline Cyprus & 4539.0 & 11930.3 & 1546.9 & 2505.1 & 34.1 & 21.0 & 162.8 & 61.9 \\
\hline Dominica & 108.9 & 117.9 & & 0.0 & 0.0 & 0.0 & 8.2 & \\
\hline Fiji & 426.3 & 705.6 & 216.1 & 0.0 & 50.7 & 0.0 & 65.5 & -100.0 \\
\hline Ghana & 504.5 & 1969.7 & & 0.0 & 0.0 & 0.0 & 290.4 & \\
\hline Grenada & 182.7 & 151.7 & & 0.0 & 0.0 & 0.0 & -17.0 & \\
\hline Guyana & 170.0 & 170.8 & & 0.0 & 0.0 & 0.0 & 0.5 & \\
\hline India & 16695.2 & 109739.0 & 1398.7 & 7925.1 & 8.4 & 7.2 & 557.3 & 466.6 \\
\hline Jamaica & 2027.7 & 2650.7 & 94.9 & 0.0 & 4.7 & 0.0 & 30.7 & -100.0 \\
\hline Kenya & 993.8 & 2885.4 & & 0.0 & 0.0 & 0.0 & 190.3 & \\
\hline Kiribati & 0.0 & 0.0 & & 0.0 & & & & \\
\hline Lesotho & 43.8 & 77.3 & & 0.0 & 0.0 & 0.0 & 76.6 & \\
\hline Malawi & 35.0 & 95.1 & & 0.0 & 0.0 & 0.0 & 171.8 & \\
\hline Malaysia & 14100.2 & 37080.6 & 974.4 & 1764.0 & 6.9 & 4.8 & 163.0 & 81.0 \\
\hline Maldives & 349.3 & 659.7 & & 0.0 & 0.0 & 0.0 & 88.9 & \\
\hline Malta & 1340.2 & 6595.3 & 390.5 & 1437.0 & 29.1 & 21.8 & 392.1 & 268.0 \\
\hline Mauritius & 1070.9 & 2229.5 & & 0.0 & 0.0 & 0.0 & 108.2 & \\
\hline Mozambique & 326.3 & 611.7 & & 0.0 & 0.0 & 0.0 & 87.5 & \\
\hline Namibia & 225.4 & 634.2 & & 0.0 & 0.0 & 0.0 & 181.4 & \\
\hline Nauru & & 0.0 & & & & & & \\
\hline New Zealand & 4466.1 & 12256.4 & 1610.6 & 1785.3 & 36.1 & 14.6 & 174.4 & 10.8 \\
\hline Nigeria & 1839.9 & 3655.9 & 4.0 & 932.1 & 0.2 & 25.5 & 98.7 & 22972.4 \\
\hline
\end{tabular}




\begin{tabular}{lcccccccc} 
Pakistan & 1380.0 & 3983.1 & 22.2 & 568.4 & 1.6 & 14.3 & $\mathbf{1 8 8 . 6}$ & $\mathbf{2 4 5 8 . 0}$ \\
Papua New Guinea & 318.6 & 195.6 & 96.5 & 0.0 & $\mathbf{3 0 . 3}$ & 0.0 & -38.6 & -100.0 \\
Rwanda & 59.8 & 341.1 & & 0.0 & 0.0 & 0.0 & $\mathbf{4 7 0 . 7}$ & \\
Samoa & 0.3 & 149.1 & 0.3 & 0.0 & $\mathbf{1 0 0 . 0}$ & 0.0 & $\mathbf{4 6 6 5 4 . 5}$ & -100.0 \\
Seychelles & 287.8 & 404.1 & & 0.0 & 0.0 & 0.0 & 40.4 & \\
Sierra Leone & 42.7 & 52.5 & & 0.0 & 0.0 & 0.0 & 23.0 & \\
Singapore & $\mathbf{2 8 8 8 0 . 9}$ & $\mathbf{9 4 6 2 0 . 2}$ & $\mathbf{4 0 4 9 . 1}$ & $\mathbf{2 0 6 5 5 . 1}$ & 14.0 & 21.8 & $\mathbf{2 2 7 . 6}$ & $\mathbf{4 1 0 . 1}$ \\
Solomon Islands & 52.2 & 70.9 & & 0.0 & 0.0 & 0.0 & 35.7 & \\
South Africa & 5453.7 & $\mathbf{1 7 7 0 6 . 7}$ & 1074.4 & $\mathbf{2 6 4 2 . 7}$ & 19.7 & 14.9 & $\mathbf{2 2 4 . 7}$ & $\mathbf{1 4 6 . 0}$ \\
Sri Lanka & 940.3 & 1892.4 & 1.5 & 0.0 & 0.2 & 0.0 & 101.3 & -100.0 \\
St. Kitts and Nevis & 104.0 & 131.9 & & 0.0 & 0.0 & 0.0 & 26.8 & \\
St. Lucia & 332.8 & 352.6 & & 0.0 & 0.0 & 0.0 & 6.0 & \\
St. Vincent and the & 143.1 & 138.9 & & 0.0 & 0.0 & 0.0 & -2.9 & \\
Grenadines & 289.4 & 200.8 & 181.7 & 105.4 & $\mathbf{6 2 . 8}$ & $\mathbf{5 2 . 5}$ & -30.6 & $\mathbf{- 4 2 . 0}$ \\
Swaziland & 628.2 & 1854.7 & & 0.0 & 0.0 & 0.0 & $\mathbf{1 9 5 . 2}$ & \\
Tanzania & 0.0 & 34.8 & & 0.0 & & 0.0 & & \\
Tonga & 555.3 & 764.8 & 41.1 & 0.0 & 7.4 & 0.0 & 37.7 & -100.0 \\
Trinidad and Tobago & 0.0 & 0.0 & & & & & & \\
Tuvalu & 213.7 & 966.3 & & 0.0 & 0.0 & 0.0 & $\mathbf{3 5 2 . 2}$ & \\
Uganda & $\mathbf{1 3 9 2 2 4 . 0}$ & $\mathbf{3 0 7 7 0 6 . 0}$ & $\mathbf{9 9 4 1 . 5}$ & $\mathbf{3 4 0 8 3 . 6}$ & 7.1 & 11.1 & 121.0 & $\mathbf{2 4 2 . 8}$ \\
United Kingdom & 129.8 & 227.1 & & 0.0 & 0.0 & 0.0 & 75.0 & \\
Vanuatu & 115.0 & 240.9 & & 0.0 & 0.0 & 0.0 & 109.5 & \\
Zambia & $\mathbf{5 6 7 5 . 1}$ & $\mathbf{1 4 0 0 5 . 4}$ & $\mathbf{1 3 7 2 . 5}$ & $\mathbf{1 7 5 9 . 9}$ & $\mathbf{1 2 . 5}$ & $\mathbf{5 . 1}$ & $\mathbf{1 2 0 9 . 3}$ & $\mathbf{1 1 3 3 . 3}$ \\
\hline \hline Average & & & & & & & \\
\hline \hline
\end{tabular}

Source: Francois \& Pindyuk (2013); own calculations

The composition of intra-CW average services trade in 2009 reveals that unallocated services accounted for $34.6 \%$ of intra-CW services trade in that year (see Figure 12). Of those allocated, OBS, transportation, travel and PCR accounted for more than 90\%; all other services contributed the remaining $8 \%$ (of which government, financial, insurance and construction services were the major sectors). 
Figure 12: Composition of intra-CW average services trade (\% shares, 2009)

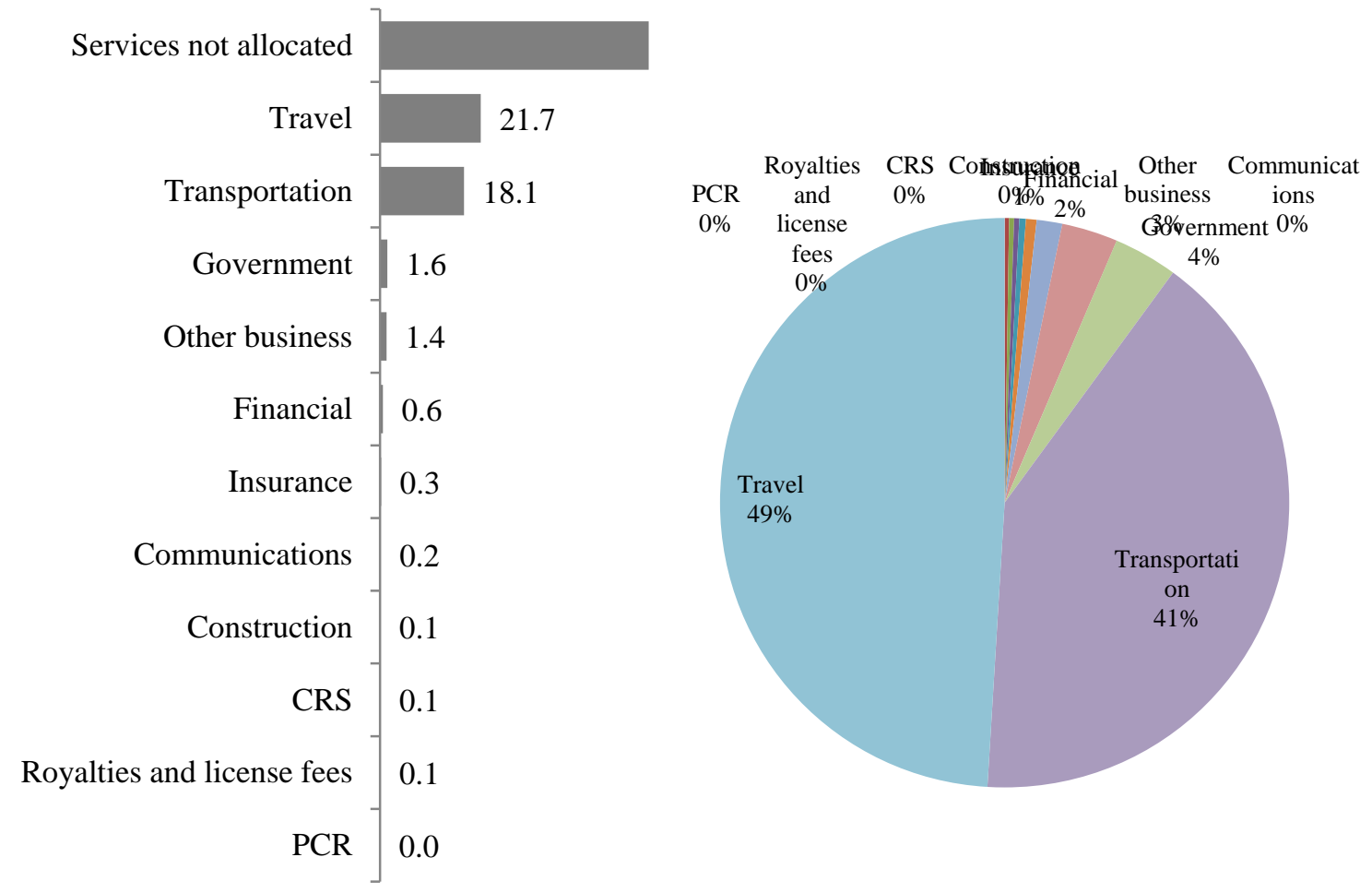

Source: Francois \& Pindyuk (2013); own calculations

Note: CRS $=$ Computer and related services; PCR $=$ Personal, cultural and recreation services; OBS $=$ Other business services

Intra-CW trade in other business services was dominated by merchanting and other traderelated services which contributed more than 95\% of total intra-CW trade in OBS in 2009. The other important OBS traded within the CW included business, management consulting and public relations services and advertising and market research services. Intra-CW trade in transportation services was dominated by sea (primarily freight) and air (primarily passenger) transport services, together contributing $62.8 \%$ of total intra-CW trade in transportation services in 2009. Intra-CW trade in travel services was dominated by personal travel services, which contributed more than $75 \%$ of total intra-CW trade in travel services in 2009 (see Tables 6-8).

Table 6: Breakdown of intra-CW trade in other business services (2009)

\begin{tabular}{|c|c|c|c|}
\hline Other business services (value in $\mathbf{\$} \mathbf{~ m n}$ ) & 14310.8 & Shares (\%) & $\begin{array}{c}\text { Shares } \\
(\%)\end{array}$ \\
\hline Merchanting and other trade-related services & 13611.9 & 95.1 & \\
\hline Operational leasing services & 11.5 & 0.1 & \\
\hline Miscellaneous business, professional, and technical services & 600.4 & 4.2 & \\
\hline Legal, accounting, management consulting, and public relations & 246.2 & & 41.0 \\
\hline Legal services & 52.3 & & 8.7 \\
\hline Accounting, auditing, bookkeeping, and tax consulting services & 44.5 & & 7.4 \\
\hline
\end{tabular}


Business and management consulting and public relations services

Advertising, market research, and public opinion polling

Research and development

Architectural, engineering, and other technical services

Agricultural, mining, and on-site processing services

Other business services

Services between related enterprises, n.i.e.
138.7

90.7

15.1

$4.5 \quad 0.0$

$26.8 \quad 0.2$

$2.9 \quad 0.0$

$209.7 \quad 1.5$

$0.0 \quad 0.0$

Source: Francois \& Pindyuk (2013); own calculations

Table 7: Breakdown of intra-CW trade in transportation services (2009)

\begin{tabular}{|c|c|c|c|}
\hline Transportation services (value in \$ mn) & 11772.8 & Shares (\%) & $\begin{array}{c}\text { Shares } \\
(\%)\end{array}$ \\
\hline Sea transport & 4102.6 & 34.8 & \\
\hline Passenger & 688.7 & & 16.8 \\
\hline Freight & 2739.7 & & 66.8 \\
\hline Other & 678.0 & & 16.5 \\
\hline Air transport & 3285.9 & 27.9 & \\
\hline Passenger & 1627.8 & & 49.5 \\
\hline Freight & 213.1 & & 6.5 \\
\hline Other & 1444.4 & & 44.0 \\
\hline Other transport & 111.5 & 0.9 & \\
\hline Passenger & 64.2 & & 57.5 \\
\hline Freight & 33.6 & & 30.2 \\
\hline Other & 13.5 & & 12.1 \\
\hline Other transport of which: Space transport & 0.0 & 0.0 & \\
\hline Other transport of which: Rail transport & 72.1 & 0.6 & \\
\hline Passenger & 64.2 & & 89.0 \\
\hline Freight & 7.7 & & 10.6 \\
\hline Other & 0.0 & & 0.0 \\
\hline Other transport of which: Road transport & 19.1 & 0.2 & \\
\hline Passenger & 0.0 & & 0.0 \\
\hline Freight & 18.8 & & 98.3 \\
\hline Other & 0.0 & & 0.0 \\
\hline Other transport of which: Inland waterway transport & 0.0 & 0.0 & \\
\hline Passenger & 0.0 & & \\
\hline Freight & 0.0 & & \\
\hline Other & 0.0 & & \\
\hline Other transport of which: Pipeline transport and electricity transmission & 0.0 & 0.0 & \\
\hline Other transport of which: Other supporting and auxiliary transport services & 1.0 & 0.0 & \\
\hline
\end{tabular}

Source: Francois \& Pindyuk (2013); own calculations 
Table 8: Breakdown of intra-CW trade in travel services (2009)

\begin{tabular}{lccc}
\hline Travel services (value in \$ mn) & $\mathbf{1 1 2 3 2 . 7}$ & Shares (\%) & $\begin{array}{c}\text { Shares } \\
\text { (\%) }\end{array}$ \\
\hline \hline Business travel & 1587.7 & 14.1 & \\
Expenditure by seasonal and border workers & 82.6 & & 5.2 \\
Other & 1507.9 & & 95.0 \\
Personal travel & 8465.1 & 75.4 & \\
Health-related expenditure & 34.4 & & 0.4 \\
Education-related expenditure & 891.7 & & 10.5 \\
Other & 7541.9 & 89.1 \\
\hline \hline
\end{tabular}

Source: Francois \& Pindyuk (2013); own calculations

\section{Bilateral trade costs}

Arvis et al. (2013) have used the inverse form of the gravity model developed by Novy (2013) to infer trade costs from the observed pattern of trade and production across countries. Their efforts have led to a joint UNESCAP-World Bank database on bilateral trade costs (BTC) for up to 178 countries over 1995-2010.

Their measure of BTC is the geometric average of international trade costs between countries $\mathrm{i}$ and $\mathrm{j}$ relative to domestic trade costs within each country. They capture the intuitive fact that trade costs are higher when countries tend to trade more within themselves than they do with each other. In contrast, when countries trade more internationally than domestically, international trade costs must be falling relative to domestic trade costs.

Importantly, this measure of BTC is a "top down" measure as it uses theory to infer trade costs from the observed pattern of trade and production across countries. Unlike "bottom up" measures, their measure of BTC includes all factors that contribute to the standard definition of iceberg trade costs in trade models i.e. anything that drives a wedge between the producer price in the exporting country and the consumer price in the importing country. Thus, BTCs include both observable and unobservable factors. Tariffs and traditional non-tariff measures are only one component of the overall measure of BTC; others include transport costs, behind-the-border barriers, and costs linked to the performance of trade logistics and facilitation services.

An analysis of the BTC from this database for different sample partners reveals that BTC are the lowest amongst intra-CW trading partners ${ }^{6}$ and have been so consistently over time (see Figure 13). Interestingly, BTC when only one of the two trading partners is from the CW are the highest and much higher than the BTC amongst two non-CW trading partners or even two intra-CW trading partners. These results support the findings of declining $\mathrm{CW}$ trade as a share of global merchandise trade and rising intra-CW trade as a share of the commonwealth's global merchandise trade over time shown in Figure 1.

\footnotetext{
${ }^{6}$ Data on Nauru are not available in the BTC database.
} 
Figure 13: Average bilateral trade costs over time amongst different sample partners

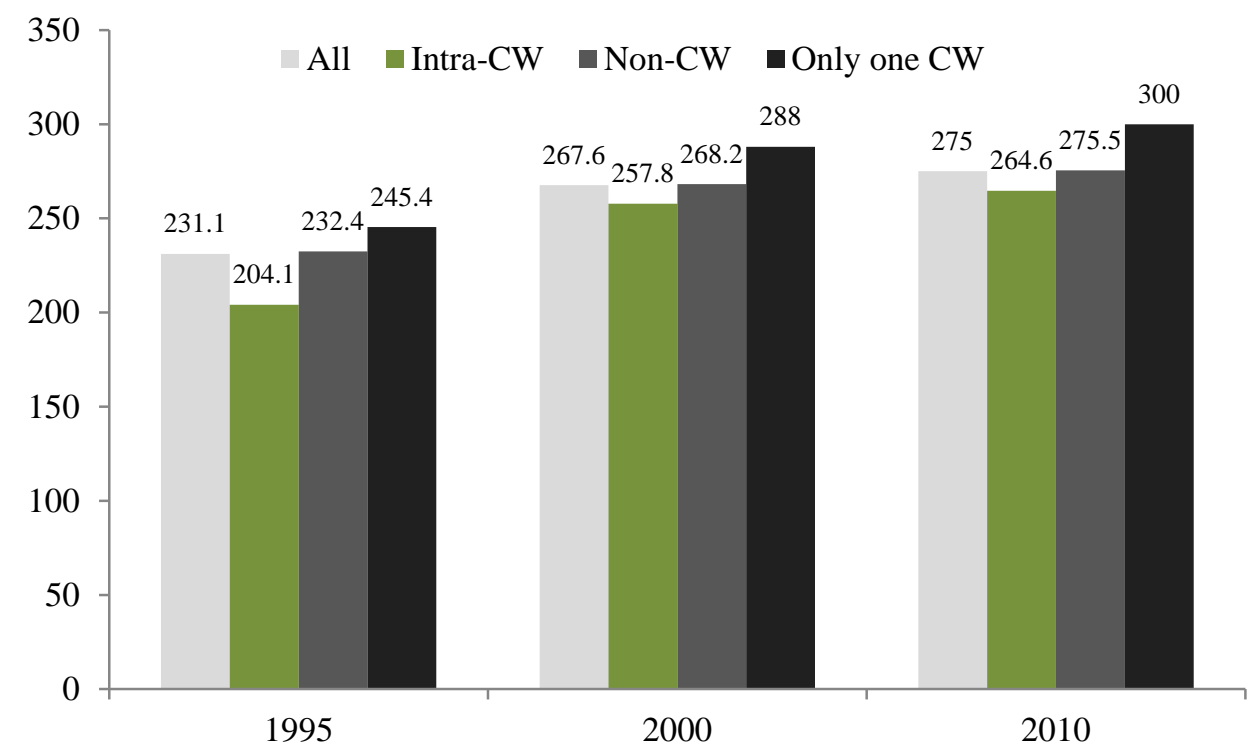

Source: Arvis et.al. (2013); own calculations

Further analyses of these BTC by region, reported in Table 9, reveal that the intra-regional BTC in 1995 were lower than the average intra-CW BTC in that year. Moreover, even the cross-regional BTC between Asia-Europe, Asia-Pacific and Caribbean-Europe were lower than the average intra-CW BTC in 1995. In contrast, the BTC between all other regions were higher than the average intra-CW BTC in 1995. In the year 2000, with the exception of CW Africa, the intra-regional BTC were still lower than the average intra-CW BTC in that year. The cross-regional BTC between Africa-Europe, Asia-Europe, Asia-Pacific and CaribbeanEurope were also lower than the average intra-CW BTC in 2000. The BTC between all other regions were higher than the average intra-CW BTC in 2000. The intra-regional pattern of BTC in 2010 was similar to that in 2000 with the exception that Asia-Pacific BTC were now higher than the average intra-CW BTC (see Table 9).

Table 9: Average intra-CW bilateral trade costs over time by region

\begin{tabular}{lccccc|ccccc}
\hline & \multicolumn{4}{c}{ Average BTC, 1995 } & \multicolumn{4}{c}{ Average BTC, 2010 } \\
& Africa & Asia & Caribbean & Europe & Pacific & Africa & Asia & Caribbean & Europe & Pacific \\
\hline \hline Africa & $\mathbf{1 8 9 . 3}$ & 235.2 & 305.0 & 205.7 & 302.9 & 275.4 & 276.2 & 477.9 & $\mathbf{1 5 6 . 3}$ & 310.2 \\
Asia & 235.2 & $\mathbf{1 7 3 . 5}$ & 263.9 & $\mathbf{1 9 7 . 6}$ & $\mathbf{1 7 5 . 9}$ & 276.2 & $\mathbf{1 5 2 . 4}$ & 397.1 & $\mathbf{1 2 6 . 4}$ & 271.8 \\
Caribbean & 305.0 & 263.9 & $\mathbf{1 2 2 . 0}$ & $\mathbf{1 7 7 . 5}$ & 215.9 & 477.9 & 397.1 & $\mathbf{1 3 9 . 8}$ & $\mathbf{1 7 4 . 2}$ & 359.2 \\
Europe & 205.7 & $\mathbf{1 9 7 . 6}$ & $\mathbf{1 7 7 . 5}$ & $\mathbf{1 2 5 . 8}$ & 227.5 & $\mathbf{1 5 6 . 3}$ & $\mathbf{1 2 6 . 4}$ & $\mathbf{1 7 4 . 2}$ & n.a. & 282.0 \\
Pacific & 302.9 & $\mathbf{1 7 5 . 9}$ & 215.9 & 227.5 & $\mathbf{1 3 4 . 1}$ & 310.2 & 271.8 & 359.2 & 282.0 & $\mathbf{2 2 8 . 8}$ \\
\hline \hline
\end{tabular}

Source: Arvis et.al. (2013); own calculations

Note: The highlighted figures are lower than the intra-CW average BTC in that year.

Finally, a breakdown of BTC by individual CW member states for 2000 and 2010, reported in Table 10, shows that there are more CW countries for which BTC are significantly lower within the CW region than outside it and this was found to be especially true for Caribbean 
and Pacific island states. For e.g. in the case of Dominica, intra-CW trade costs were only $40 \%$ of extra-CW trade costs in 2010. St. Vincent and Grenadines had 30\% lower intra-CW trade costs in 2000 (50\% lower in 2010). In contrast, for the Bahamas and Ghana, intra-CW BTC were 1.2 times extra-CW BTC.

On average, both intra- and extra-CW BTC went up over 2000-2010, with the average change being $6.7 \%$ and $3.6 \%$, respectively. In some cases, such as Antigua \& Barbuda (38.8\% and $54.8 \%$ ), Barbados (42.9\% and 16.1\%), Botswana (27.1\% and 35.9\%), the rise was much greater than these averages, both within and outside the CW. At the same time, several CW members including Australia (-5.4\% and $-3.7 \%)$, India (-19.9\% and $-11 \%)$, Namibia $(-10.2 \%$ and $-12.5 \%)$, Nigeria (-6.8\% and $-11.9 \%$ ) show a fall in BTC over $2000-10$ and in some cases, this decline has been significant for e.g. Dominica, Kenya, St. Kitts and Nevis saw a more than 30\% fall in intra-CW BTC over 2000-2010.

One interesting finding from the discussion in this section is that the Arvis et.al.(2013) measure of BTC has gone up over time. Since the BTC is a measure of international trade costs relative to domestic trade costs, a rise in BTC over time could mean any or all of the following: (i) international trade costs have increased over time (ii) domestic trade costs have fallen over time (iii) a combination of (i) and (ii).

Table 10: Intra- and extra-CW bilateral trade costs by CW member (2000, 2010)

\begin{tabular}{|c|c|c|c|c|c|c|c|c|}
\hline \multirow{2}{*}{$\begin{array}{l}\text { Bilateral trade costs } \\
\text { (BTC) } \\
\text { Commonwealth member } \\
\end{array}$} & \multicolumn{2}{|c|}{2000} & \multicolumn{2}{|c|}{2010} & \multirow{2}{*}{$\begin{array}{c}2000 \\
\text { Intra/Extr } \\
\mathbf{a} \\
\end{array}$} & \multirow{2}{*}{$\begin{array}{c}2010 \\
\text { Intra/Extr } \\
\mathbf{a} \\
\end{array}$} & \multicolumn{2}{|c|}{$\begin{array}{c}\text { \% change over 2000- } \\
10\end{array}$} \\
\hline & $\begin{array}{c}\text { IntraC } \\
\mathbf{W}\end{array}$ & $\begin{array}{c}\text { ExtraC } \\
\mathrm{W}\end{array}$ & $\begin{array}{c}\text { IntraC } \\
\mathrm{W}\end{array}$ & $\begin{array}{c}\text { ExtraC } \\
\mathrm{W}\end{array}$ & & & $\begin{array}{c}\text { IntraC } \\
\mathbf{W}\end{array}$ & $\begin{array}{c}\text { ExtraC } \\
\mathrm{W}\end{array}$ \\
\hline Antigua and Barbuda & 167.3 & 228.9 & 232.3 & 354.5 & 0.7 & 0.7 & 38.8 & 54.8 \\
\hline Australia & 254.2 & 282.9 & 240.3 & 272.4 & 0.9 & 0.9 & -5.4 & -3.7 \\
\hline Bahamas, The & 296.5 & 273.1 & 355.0 & 292.6 & 1.1 & 1.2 & 19.7 & 7.1 \\
\hline Bangladesh & 319.6 & 300.8 & & & 1.1 & & & \\
\hline Barbados & 226.5 & 358.8 & 323.8 & 416.4 & 0.6 & 0.8 & 42.9 & 16.1 \\
\hline Belize & 269.0 & 328.8 & 287.1 & 298.7 & 0.8 & 1.0 & 6.7 & -9.2 \\
\hline Botswana & 263.8 & 285.6 & 335.3 & 388.3 & 0.9 & 0.9 & 27.1 & 35.9 \\
\hline Brunei Darussalam & 305.0 & 359.5 & & & 0.8 & & & \\
\hline Cameroon & 373.9 & 308.6 & 323.1 & 314.3 & 1.2 & 1.0 & -13.6 & 1.9 \\
\hline Canada & 262.8 & 244.8 & & & 1.1 & & & \\
\hline Cyprus & 322.3 & 278.4 & & & 1.2 & & & \\
\hline Dominica & 168.9 & 275.2 & 111.9 & 268.0 & 0.6 & 0.4 & -33.8 & -2.6 \\
\hline Fiji & 257.0 & 348.4 & 238.8 & 421.8 & 0.7 & 0.6 & -7.1 & 21.1 \\
\hline Ghana & 280.8 & 256.0 & 353.9 & 307.7 & 1.1 & 1.2 & 26.1 & 20.2 \\
\hline Grenada & 142.8 & 289.3 & & & 0.5 & & & \\
\hline Guyana & 166.8 & 261.1 & 221.2 & 304.6 & 0.6 & 0.7 & 32.6 & 16.7 \\
\hline India & 268.8 & 238.8 & 215.4 & 212.6 & 1.1 & 1.0 & -19.9 & -11.0 \\
\hline Jamaica & 244.0 & 295.8 & 282.5 & 357.1 & 0.8 & 0.8 & 15.7 & 20.7 \\
\hline Kenya & 266.8 & 289.0 & 167.3 & 296.1 & 0.9 & 0.6 & -37.3 & 2.5 \\
\hline Kiribati & 188.4 & 263.4 & 239.6 & 281.6 & 0.7 & 0.9 & 27.1 & 6.9 \\
\hline Lesotho & 350.7 & 313.1 & & & 1.1 & & & \\
\hline Malawi & 316.3 & 330.1 & 273.1 & 355.5 & 1.0 & 0.8 & -13.7 & 7.7 \\
\hline Malaysia & 218.4 & 219.4 & 203.4 & 224.2 & 1.0 & 0.9 & -6.9 & 2.2 \\
\hline
\end{tabular}




\begin{tabular}{|c|c|c|c|c|c|c|c|c|}
\hline Maldives & 224.1 & 313.8 & 304.5 & 326.8 & 0.7 & 0.9 & 35.9 & 4.1 \\
\hline Malta & 275.1 & 237.4 & & & 1.2 & & & \\
\hline Mauritius & 259.2 & 307.9 & 256.7 & 342.5 & 0.8 & 0.7 & -0.9 & 11.2 \\
\hline Mozambique & 256.4 & 309.2 & 233.5 & 317.1 & 0.8 & 0.7 & -8.9 & 2.6 \\
\hline Namibia & 306.9 & 317.2 & 275.6 & 277.7 & 1.0 & 1.0 & -10.2 & -12.5 \\
\hline New Zealand & 260.8 & 285.6 & & & 0.9 & & & \\
\hline Nigeria & 355.5 & 330.0 & 331.5 & 290.8 & 1.1 & 1.1 & -6.8 & -11.9 \\
\hline Pakistan & & & 280.8 & 268.1 & & 1.0 & & \\
\hline Papua New Guinea & 257.0 & 322.5 & 248.4 & 250.3 & 0.8 & 1.0 & -3.4 & -22.4 \\
\hline Rwanda & 334.7 & 381.0 & 353.8 & 479.1 & 0.9 & 0.7 & 5.7 & 25.7 \\
\hline Samoa & & & 282.4 & 430.0 & & 0.7 & & \\
\hline Seychelles & 299.7 & 354.7 & & & 0.8 & & & \\
\hline Sierra Leone & 289.7 & 315.1 & & & 0.9 & & & \\
\hline Singapore & 311.3 & 338.4 & 292.8 & 313.0 & 0.9 & 0.9 & -6.0 & -7.5 \\
\hline South Africa & 224.3 & 287.6 & 233.5 & 256.9 & 0.8 & 0.9 & 4.1 & -10.7 \\
\hline Sri Lanka & 216.4 & 228.0 & 304.5 & 270.3 & 0.9 & 1.1 & 40.7 & 18.6 \\
\hline St. Kitts and Nevis & 239.8 & 443.8 & 160.8 & 350.5 & 0.5 & 0.5 & -32.9 & -21.0 \\
\hline St. Lucia & 143.2 & 350.6 & & & 0.4 & & & \\
\hline $\begin{array}{l}\text { St. Vincent and the } \\
\text { Grenadines }\end{array}$ & 109.3 & 377.1 & 128.9 & 271.5 & 0.3 & 0.5 & 17.9 & -28.0 \\
\hline Swaziland & 276.4 & 325.9 & & & 0.8 & & & \\
\hline Tanzania & 259.2 & 335.7 & 240.5 & 322.5 & 0.8 & 0.7 & -7.2 & -3.9 \\
\hline Tonga & 255.1 & 487.1 & 463.4 & 526.9 & 0.5 & 0.9 & 81.7 & 8.2 \\
\hline Trinidad and Tobago & 259.8 & 287.0 & & & 0.9 & & & \\
\hline Uganda & 300.4 & 365.3 & 372.3 & 358.9 & 0.8 & 1.0 & 24.0 & -1.7 \\
\hline United Kingdom & 156.2 & 161.6 & 180.2 & 162.3 & 1.0 & 1.1 & 15.4 & 0.4 \\
\hline Vanuatu & & & 305.5 & 362.5 & & 0.8 & & \\
\hline Zambia & 288.4 & 393.0 & 226.6 & 336.0 & 0.7 & 0.7 & -21.4 & -14.5 \\
\hline Average & 257.2 & 308.2 & 267.0 & 321.1 & 0.9 & 0.8 & 6.7 & 3.6 \\
\hline
\end{tabular}

Source: Arvis et. al. (2013); own calculations

\section{Results from estimation}

Table 11 reports the results from the 2WFE estimation of our baseline specification for bilateral goods and services trade; the dependent variable incorporates "export zeroes" in each case. All estimations include time-varying importer and exporter fixed effects to control for multilateral resistance. Standard errors are clustered by trading partner pair and year. For the sake of comparison, columns (2) and (4) also report the results from estimating equation (2) for bilateral goods and services trade, respectively, replacing the standard gravity controls described in Section 3 with data on ad valorem bilateral trade costs from Arvis et.al (2013). Since the latter are a measure of both observed and unobserved factors that impose a cost on trading in general, they can be used in both the goods and services trade equations. 
Table 11: Estimation results

\begin{tabular}{|c|c|c|c|c|}
\hline & $\begin{array}{c}\text { Goods } \\
\ln \left(X_{\mathrm{ijt}}+\right. \\
\left.\min _{\mathrm{j}}\right) \\
2 \mathrm{WFE} \\
(1)\end{array}$ & $\begin{array}{c}\text { Goods } \\
\ln \left(X_{\mathrm{ijt}}+\right. \\
\left.\min _{\mathrm{j}}\right) \\
2 \mathrm{WFE} \\
(2)\end{array}$ & $\begin{array}{c}\text { Services } \\
\ln \left(X_{i j t}+\right. \\
\left.\text { min }_{j}\right) \\
2 W F E \\
\text { (3) }\end{array}$ & $\begin{array}{c}\text { Services } \\
\ln \left(X_{\mathrm{ijt}}+\right. \\
\left.\min _{\mathrm{j}}\right) \\
2 \mathrm{WFE} \\
\text { (4) }\end{array}$ \\
\hline Commonwealth membership & $\begin{array}{c}0.170 * * \\
(0.062)\end{array}$ & $\begin{array}{c}0.287 * * * \\
(0.039)\end{array}$ & $\begin{array}{l}-0.033 \\
(0.044)\end{array}$ & $\begin{array}{c}0.356^{* * *} \\
(0.047)\end{array}$ \\
\hline PTA membership & $\begin{array}{c}0.259 * * * \\
(0.034)\end{array}$ & & $\begin{array}{c}-0.231 * * * \\
(0.032)\end{array}$ & \\
\hline $\ln (\mathrm{BTC})$ & & $\begin{array}{c}-3.958 * * * \\
(0.028)\end{array}$ & & $\begin{array}{c}-1.99 * * * \\
(0.023)\end{array}$ \\
\hline Contiguity & $\begin{array}{c}0.219 * * * \\
(0.055)\end{array}$ & & $\begin{array}{c}0.235^{* * *} \\
(0.052)\end{array}$ & \\
\hline Common language & $\begin{array}{c}0.150^{* * *} \\
(0.042)\end{array}$ & & $\begin{array}{c}0.152^{* * *} \\
(0.028)\end{array}$ & \\
\hline $\ln ($ distance $)$ & $\begin{array}{c}-1.551^{* * *} \\
(0.021)\end{array}$ & & $\begin{array}{c}-0.976 * * * \\
(0.015)\end{array}$ & \\
\hline Common colony & $\begin{array}{c}0.948^{* * *} \\
(0.049)\end{array}$ & & $\begin{array}{c}0.849 * * * \\
(0.039)\end{array}$ & \\
\hline Common legal system & $\begin{array}{c}0.626^{* * *} \\
(0.021)\end{array}$ & & $\begin{array}{c}0.377^{* * *} \\
(0.015)\end{array}$ & \\
\hline Common currency & $\begin{array}{c}-1.023^{* * *} \\
(0.073)\end{array}$ & & $\begin{array}{c}-0.496 * * * \\
(0.050)\end{array}$ & \\
\hline $\mathrm{N}$ & 96328 & 70839 & 97009 & 70839 \\
\hline r2 & 0.879 & 0.908 & 0.779 & 0.788 \\
\hline Fixed effects: & & & & \\
\hline Importer*time & Yes & Yes & Yes & Yes \\
\hline Exporter*time & Yes & Yes & Yes & Yes \\
\hline
\end{tabular}

Note: (1) Levels of significance: $\# 10 \%, * 5 \%, * * 1 \%,{ }^{* * *} 0.1 \%$ (2) Standard errors, reported in parentheses, are clustered by trading partner pair and year

In the results reported in columns (1) and (3), commonwealth membership is found to increase goods exports by $18.5 \%$, ceteris paribus and on average, while the impact of commonwealth membership on services exports is found to be statistically indifferent from zero.

With the exception of common currency, the impact of all other gravity controls is as expected and consistent with existing literature. Countries with a common language/legal system/colonial relationships or which are adjacent to each other also export larger values of goods and services to each other. Distance and having a common currency are found to reduce the value of trade between partners for both goods and services. PTA membership has a positive impact on goods exports though not on services exports. 
In the results reported in columns (2) and (4), the effect of commonwealth membership is accentuated and it is found to increase goods exports by $33.2 \%$ and services exports by $42.8 \%$, ceteris paribus and on average. These results also suggest that a $1 \%$ rise in ad valorem bilateral trade costs is associated with a $4 \%$ decline in goods trade and a $2 \%$ fall in services trade, ceteris paribus and on average.

\section{Determinants of intra-CW goods and services trade}

In complimentary empirical analyses, we also examine the determinants of intra-CW goods and services trade in line with equation (2). The dependent variable is now export value from $\mathrm{i}$ to $\mathrm{j}$ where both $\mathrm{i}$ to $\mathrm{j}$ are members of the $\mathrm{CW}$. The dependent variable also incorporates "export zeroes" in the analyses.

These results reported in Table 12 suggest that the effect of commonwealth membership, at least for goods trade, shows itself through the presence of common language (columns 1 and 3 ) and colonial antecedents (columns 1 to 6). Geography (distance and contiguity) has a negative bearing on both goods and services trade in these results, confirming that commonwealth member states are not natural trading partners for each other.

In addition to the explanatory variables in equation (2), we also include regional dummy variables (columns 2 and 5) corresponding to the different regions of the CW (as shown in figures 4, 5, 10 and 11). In distinct specifications (columns 3 and 6), we also include a dummy variable for a trading partner being either one of Australia, Canada or the UK (ABC dummy) to examine the importance of these three countries in intra-CW goods and services trade.

The ABC dummy is statistically significant only for goods trade and the coefficient on this variable suggests that being an ABC country is associated with $98.2 \%$ greater merchandise trade than the average within the commonwealth member states.

In terms of regions within the CW, only Asian CW member states are associated with higher than average goods and services trade, with the magnitude of the latter twice that of the former. Caribbean, European and Pacific CW, in contrast, are associated with less than average goods and services trade. Significantly, these findings are consistent with the stylized facts in Section 4 that show the importance of the Asian CW region as both a source of and destination for intra-CW goods and services trade.

Table 12: Determinants of intra-CW goods and services trade

\begin{tabular}{|c|c|c|c|c|c|c|}
\hline & $\begin{array}{c}\text { Goods } \\
\ln \left(X_{i j t}+\right. \\
\left.\min _{\mathbf{j}}\right)\end{array}$ & $\begin{array}{c}\text { Goods } \\
\ln \left(X_{i j t}+\right. \\
\left.\min _{\mathbf{j}}\right)\end{array}$ & $\begin{array}{c}\text { Goods } \\
\ln \left(X_{i j t}+\right. \\
\left.\min X_{i}\right)\end{array}$ & $\begin{array}{c}\text { Services } \\
\ln \left(X_{i j t}+\right. \\
\left.\min _{\mathbf{i}}\right)\end{array}$ & $\begin{array}{c}\text { Services } \\
\ln \left(X_{i j t}+\right. \\
\left.\min _{\mathbf{j}}\right)\end{array}$ & $\begin{array}{c}\text { Services } \\
\ln \left(X_{i j t}+\right. \\
\left.\min _{\mathbf{j}}\right)\end{array}$ \\
\hline & 2WFE & 2WFE & 2WFE & 2WFE & 2WFE & 2WFE \\
\hline & $(1)$ & $(2)$ & (3) & $(4)$ & $(5)$ & $(6)$ \\
\hline \multirow[t]{2}{*}{ PTA membership } & 0.139 & 0.162 & 0.107 & 0.398 & $\begin{array}{l}-0.094 \\
\end{array}$ & 0.400 \\
\hline & $(0.198)$ & $(0.193)$ & $(0.197)$ & $(0.244)$ & $(0.235)$ & $(0.247)$ \\
\hline Contiguity & $-1.511^{*}$ & -0.280 & $-1.523^{*}$ & $-2.555^{* * *}$ & $-1.416^{*}$ & $-2.554 * * *$ \\
\hline
\end{tabular}




\begin{tabular}{|c|c|c|c|c|c|c|}
\hline & $(0.668)$ & $(0.656)$ & $(0.670)$ & $(0.660)$ & $(0.674)$ & $(0.661)$ \\
\hline \multirow[t]{2}{*}{ Common language } & $0.690^{*}$ & 0.254 & $0.744^{*}$ & -0.340 & -0.237 & -0.341 \\
\hline & $(0.325)$ & $(0.265)$ & $(0.328)$ & $(0.272)$ & $(0.264)$ & $(0.273)$ \\
\hline \multirow[t]{2}{*}{$\ln$ (distance) } & $-1.689 * * *$ & $-1.295^{* * *}$ & $-1.705^{* * *}$ & $-0.935 * * *$ & $-0.544 * * *$ & $-0.934 * * *$ \\
\hline & $(0.128)$ & $(0.182)$ & $(0.127)$ & $(0.113)$ & $(0.154)$ & $(0.113)$ \\
\hline \multirow[t]{2}{*}{ Common colony } & $2.146^{* * *}$ & $2.025 * * *$ & $2.156^{* * *}$ & $0.935^{* * *}$ & $0.824 * * *$ & $0.935^{* * *}$ \\
\hline & $(0.358)$ & $(0.358)$ & $(0.359)$ & $(0.217)$ & $(0.203)$ & $(0.217)$ \\
\hline \multirow{2}{*}{$\begin{array}{l}\text { Common legal } \\
\text { system }\end{array}$} & 0.601 & 0.652 & 0.633 & 0.369 & $0.558 \#$ & 0.368 \\
\hline & $(0.561)$ & $(0.560)$ & $(0.562)$ & $(0.339)$ & $(0.335)$ & $(0.340)$ \\
\hline \multirow[t]{2}{*}{ Common currency } & $-2.374 *$ & -0.933 & $-2.329 *$ & 0.696 & 0.340 & 0.695 \\
\hline & $(0.948)$ & $(0.674)$ & $(0.948)$ & $(0.852)$ & (0.958) & $(0.852)$ \\
\hline \multirow[t]{2}{*}{ Caribbean } & & $-1.504 * *$ & & & $-0.777^{*}$ & \\
\hline & & $(0.462)$ & & & $(0.374)$ & \\
\hline \multirow[t]{2}{*}{ Africa } & & 3.690\# & & & -1.159 & \\
\hline & & $(2.142)$ & & & $(1.272)$ & \\
\hline \multirow[t]{2}{*}{ Europe } & & $-0.914 *$ & & & $-2.606 * * *$ & \\
\hline & & $(0.356)$ & & & $(0.353)$ & \\
\hline \multirow[t]{2}{*}{ Asia } & & $0.660^{*}$ & & & $1.291^{* * *}$ & \\
\hline & & $(0.286)$ & & & $(0.362)$ & \\
\hline \multirow[t]{2}{*}{ Pacific } & & $-1.596^{* * *}$ & & & $-1.586^{* * *}$ & \\
\hline & & $(0.444)$ & & & $(0.336)$ & \\
\hline \multirow[t]{2}{*}{$\mathrm{ABC}$} & & & $0.684 * * *$ & & & -0.022 \\
\hline & & & $(0.193)$ & & & $(0.244)$ \\
\hline $\mathrm{N}$ & 2626 & 2626 & 2626 & 2626 & 2626 & 2626 \\
\hline r2 & 0.912 & 0.914 & 0.912 & 0.835 & 0.847 & 0.835 \\
\hline \multicolumn{7}{|l|}{ Fixed effects: } \\
\hline Importer*time & Yes & Yes & Yes & Yes & Yes & Yes \\
\hline Exporter*time & Yes & Yes & Yes & Yes & Yes & Yes \\
\hline
\end{tabular}

Note: (1) Levels of significance: \#10\%, *5\%, **1\%, ***0.1\% (2) Standard errors, reported in parentheses, are clustered by trading partner pair and year

Finally, the findings on the determinants of intra-CW goods and services trade are robust to the use of an alternative dependent variable: the share of commonwealth in total trade.

\section{Barriers to intra-CW trade and measures to enhance intra-CW trade}

The analyses undertaken in this study reveal the growing importance of the Commonwealth member states both as a source and destination for the Commonwealth's goods and services. This said, barriers within the Commonwealth continue being high and there is ample scope for improving market access, especially for the Commonwealth LDCs that still face substantial tariffs on exports to Commonwealth developing and LDC members and for Commonwealth exporters of processed agricultural goods (for instance see ITC, 2013). 
At the global level, for instance, Commonwealth countries faced an average weighted applied tariff of $4.6 \%$ in 2012. This was the same for Commonwealth LDCs, implying no preference margin for Commonwealth LDCs exporting to the world. While Commonwealth LDCs enjoy comparatively favourable tariff conditions within the markets of the six Commonwealth developed countries (Australia, Canada, Cyprus, Malta, New Zealand, UK), they face considerable tariffs in other Commonwealth developing and LDCs (see ITC, 2013 for details). Trade-weighted average intra-LDC tariffs were as high as $11.1 \%$ in 2012 while average Commonwealth developing country tariff on LDC exports amounted to 5.9\%. Thus there is enough scope for reducing applied tariffs on LDC exports destined to other commonwealth developing countries.

In addition to reducing overall tariffs, there is scope for reducing intra-Commonwealth tariff escalation. Commonwealth countries generally faced higher tariffs for their processed than for their non-processed exports in 2012 (see ITC, 2013). Furthermore, Commonwealth tariffs on intra-Commonwealth imports were on average higher than the tariffs imposed by the rest of the world. Illustratively, processed agricultural exports of the 33 Commonwealth developing countries faced an average Commonwealth trade-weighted tariff of $20.3 \%$ compared to $16.6 \%$ in the rest of the world. Intra-commonwealth tariff liberalization would therefore particularly benefit Commonwealth developing and LDCs where the export pattern remains dominated by processed agricultural goods.

Apart from tariffs, non-tariff barriers (NTBs) such as technical standards are other significant obstacles to intra-Commonwealth trade, raising costs for exporters and serving as protective measures by importing countries (for details see Commonwealth Secretariat, 2008). Besides trade policy, there is a range of other policies as well as domestic conditions that affect the competitiveness of domestic production. There is considerable heterogeneity across the Commonwealth in the competitiveness of the policy and economic environment and considerable scope for promoting intra-Commonwealth trade by improving these domestic conditions.

While geography (remoteness and large distances) is a natural barrier to intra-commonwealth trade, international transaction costs are also raised by poor infrastructure, uncompetitive transport sectors and inefficient ports within the Commonwealth. These 'unnatural' barriers to intra-Commonwealth trade can be lowered by undertaking investment and policy reforms.

One striking finding from our empirical analyses of the determinants of intra-commonwealth goods and services trade is the statistical insignificance of PTA membership in all specifications. This suggests the scope for negotiating effective and deep agreements within contiguous regions of the Commonwealth where more targeted and focussed tariff liberalization, including for sectors with tariff peaks, may be pursued along with investment promotion and approximation/harmonization of NTBs like standards and technical barriers to trade. 
Another obvious candidate is improving supply-side capacities especially those related to infrastructure, trade facilitation and to meeting technical standards in important export sectors in Commonwealth less developing and LDCs. This can be pursued more effectively through targeted trade interventions and AfT initiatives as well as by promoting more cooperation within the Commonwealth. Trade policy capacity building within the Commonwealth should also focus on these issues, support research, set common 'Commonwealth' positions and shape the agenda in bilateral, regional and other negotiations (Commonwealth Secretariat, 2008).

On the whole, intra-Commonwealth trade can be enhanced through the simultaneous implementation of various instruments and modalities. Another such instrument could be an economic cooperation agreement amongst selected developed and developing countries within the Commonwealth, which could, inter alia, also involve technical and financial assistance in the implementation of trade facilitation measures amongst Commonwealth countries.

\section{Conclusion}

This study assembles bilateral trade flow data on goods and services for 242 countries over 1995-2010 and uses both descriptive statistics and more sophisticated econometric techniques to understand the nature and structure of intra- commonwealth trade, its determinants, and the trade effect of being a part of the commonwealth. Given the much larger existing literature on barriers to commonwealth trade, the study only briefly discusses measures available to enhance intra- commonwealth trade.

None of the econometric studies in the existing literature examining the trade effect of commonwealth membership account for the presence of zero trade flows between bilateral trading partners, unobserved heterogeneity and multilateral resistance terms (MRT) in estimation, thus leading to biased estimates. Our analyses are an improvement on all these fronts. Moreover, the existing econometric studies only look at trade in merchandise goods, while we also include services trade in our analyses. Finally, we assemble a much larger sample of bilateral trading partners (242 countries each) than in the existing literature.

In our results, commonwealth membership is found to increase goods exports by 18.5-33.2\% and services exports by $42.8 \%$, ceteris paribus and on average. Our analyses on the determinants of intra-CW goods and services trade suggest the positive role of common language (only for goods trade) and colonial relationships as well as the negative impact of geography (both distance and contiguity), thereby confirming that commonwealth member states are not natural trading partners for each other. Our empirical analyses also document the importance of the Asian CW region as both a source of and destination for intra-CW goods and services trade. Finally, being one of Australia, Canada and the UK is associated with $98.2 \%$ greater merchandise trade than the average within the commonwealth member states. However, a similar effect is not observed in the case of services trade. 


\section{References}

Anderson, J. E. (1979). 'A theoretical foundation for the gravity equation', The American Economic Review 106-116.

Anderson, J. E. and Van Wincoop, E. (2003). 'Gravity with gravitas: A solution to the border puzzle’, The American Economic Review 93(1):170-192.

Anderson, J. E. and van Wincoop, E. (2004). 'Trade costs', Journal of Economic Literature 42:691-751.

Arvis, J. F., Duval, Y., Shepherd, B., \& Utoktham, C. (2013). 'Trade costs in the developing world: 1995-2010’, World Bank Policy Research Working Paper, (6309).

Baier, S. L. and Bergstrand, J. H. (2007). 'Do free trade agreements actually increase members' international trade?', Journal of international Economics 71(1):72-95.

Baier, S. L. and Bergstrand, J. H. (2009). 'Bonus vetus ols: A simple method for approximating international trade-cost effects using the gravity equation', Journal of International Economics 77(1):77-85.

Bennett J., Sriskandarajah D. and Ware Z. (2010). 'An Uncommon Association, A Wealth of Potential: Final Report of the Commonwealth Conversation', London: Royal Commonwealth Society.

Commonwealth Secretariat (2008). 'Trading on Commonwealth Ties A Review of the Structure of Commonwealth Trade and the Scope for Developing Linkages and Trade in the Commonwealth’, Economic Paper 79, Commonwealth Economic Paper Series.

Eaton, J. and Kortum, S. (2001). 'Trade in capital goods', European Economic Review 45(7):1195-1235.

Francois, J. and Pindyuk, O. (2013). 'Consolidated data on international trade in services', IIDE Discussion Papers 2013/01/01, Institute for International and Development Economics.

Guimaraes, P. and Portugal, P. (2010). 'A simple feasible procedure to fit models with highdimensional fixed effects’, Stata Journal 10(4):628.

Harrigan, J. (1996). 'Openness to trade in manufactures in the OECD', Journal of International Economics 40(1):23-39.

Head, K. and Mayer, T. (2013). 'Gravity equations: Toolkit, cookbook, workhorse', Handbook of International Economics 4.

Head, K., Mayer, T., and Ries, J. (2010). 'The erosion of colonial trade linkages after independence', Journal of International Economics 81(1):1-14.

ITC (2013). 'Commonwealth trade: Prospects for stronger cooperation', Doc. No. MAR-13229.E, Geneva: ITC, 2013. ix, 39 pages (Technical paper) 
Lundan S. and Jones G. (2001). 'The 'Commonwealth Effect' and the Process of Internationalisation’, World Economy 24(1):99-118.

Novy, D. (2013). 'Gravity redux: measuring international trade costs with panel data’, Economic Inquiry 51(1), 101-121.

Santos Silva, J. and Tenreyro, S. (2006). 'The log of gravity', The Review of Economics and Statistics 88(4):641-658.

Santos Silva, J. and Tenreyro, S. (2010). 'On the existence of the maximum likelihood estimates in poisson regression’, Economics Letters 107(2):310-312.

Standard Chartered (2014). 'Commonwealth trade unbundled’, Global Research, 17 July. 
Annex Table 1: Summary statistics

\begin{tabular}{lccccc}
\hline Variable & Obs & Mean & $\begin{array}{c}\text { Std. } \\
\text { Dev. }\end{array}$ & Min & Max \\
\hline \hline & & & & & \\
Goods exports (\$mn) & 105251 & 1003.8 & 6666.1 & 0 & 332846.7 \\
Services exports (\$mn) & 105251 & 275.9 & 1652.8 & 0 & 62765.5 \\
Goods trade agreement & 105251 & 0.2 & 0.4 & 0 & 1 \\
Services trade agreement & 105251 & 0.1 & 0.3 & 0 & 1 \\
Contiguity & 97023 & 0.0 & 0.2 & 0 & 1 \\
Common language & 97023 & 0.1 & 0.3 & 0 & 1 \\
Distance & 97023 & 6527.9 & 4326.5 & 20.3 & 19539.5 \\
Common colony & 97023 & 0.0 & 0.2 & 0 & 1 \\
Common law & 97023 & 0.3 & 0.4 & 0 & 1 \\
Common currency & 97023 & 0.0 & 0.2 & 0 & 1 \\
Bilateral trade costs & 71087 & 204.3 & 117.0 & 0.2 & 2299.7 \\
Commonwealth_reporter & 105251 & 0.2 & 0.4 & 0 & 1 \\
Commonwealth_partner & 105251 & 0.2 & 0.4 & 0 & 1 \\
Commonwealth_both & 105251 & 0.0 & 0.2 & 0 & 1 \\
\hline \hline
\end{tabular}

Annex Table 2: Trade projections

\begin{tabular}{lcccc}
\hline Avg. trade in goods (\$bn) & $\mathbf{2 0 2 0}$ & $\mathbf{2 0 3 0}$ & $\mathbf{2 0 4 0}$ & $\mathbf{2 0 5 0}$ \\
\hline \hline World & 42966.2 & 112224.7 & 293123.1 & 765617.3 \\
Commonwealth & 4769.0 & 10254.9 & 22051.4 & 47417.9 \\
Intra-commonwealth & 891.8 & 2138.7 & 5129.0 & 12300.7 \\
\hline Avg. trade in services & & & & \\
(\$bn) & 12126.4 & 32728.1 & 88330.0 & 238394.3 \\
\hline \hline World & 2191.6 & 6281.5 & 18003.8 & 51601.5 \\
Commonwealth & 655.8 & 3999.7 & 24392.1 & 148755.9 \\
Intra-commonwealth & & & &
\end{tabular}

